\title{
Impact of climate change on hydrological conditions in a tropical West African catchment using an ensemble of climate simulations
}

\author{
Yacouba Yira $^{1}$, Bernd Diekkrüger ${ }^{1}$, Gero Steup ${ }^{1}$, and Aymar Yaovi Bossa ${ }^{2,3}$ \\ ${ }^{1}$ Department of Geography, University of Bonn, Meckenheimer Allee 166, 53115 Bonn, Germany \\ ${ }^{2}$ West African Science Service Center on Climate Change and Adapted Land Use-WASCAL, P.O. Box 9507, \\ Ouagadougou 06, Burkina Faso \\ ${ }^{3}$ Department of Hydrology and Water Resources Management, National Institute of Water, University of Abomey-Calavi, \\ P.O. Box 526, Cotonou 01, Benin \\ Correspondence to: Yacouba Yira (yira_y@uni-bonn.de)
}

Received: 28 July 2016 - Discussion started: 7 September 2016

Revised: 25 March 2017 - Accepted: 28 March 2017 - Published: 20 April 2017

\begin{abstract}
This study evaluates climate change impacts on water resources using an ensemble of six regional climate models (RCMs)-global climate models (GCMs) in the Dano catchment (Burkina Faso). The applied climate datasets were performed in the framework of the COordinated Regional climate Downscaling Experiment (CORDEXAfrica) project.

After evaluation of the historical runs of the climate models' ensemble, a statistical bias correction (empirical quantile mapping) was applied to daily precipitation. Temperature and bias corrected precipitation data from the ensemble of RCMs-GCMs was then used as input for the Water flow and balance Simulation Model (WaSiM) to simulate water balance components.

The mean hydrological and climate variables for two periods (1971-2000 and 2021-2050) were compared to assess the potential impact of climate change on water resources up to the middle of the 21 st century under two greenhouse gas concentration scenarios, the Representative Concentration Pathways (RCPs) 4.5 and 8.5. The results indicate (i) a clear signal of temperature increase of about 0.1 to $2.6^{\circ} \mathrm{C}$ for all members of the RCM-GCM ensemble; (ii) high uncertainty about how the catchment precipitation will evolve over the period 2021-2050; (iii) the applied bias correction method only affected the magnitude of the climate change signal; (iv) individual climate models results lead to opposite discharge change signals; and (v) the results for the RCMGCM ensemble are too uncertain to give any clear direction for future hydrological development. Therefore, potential in-
\end{abstract}

crease and decrease in future discharge have to be considered in climate change adaptation strategies in the catchment. The results further underline on the one hand the need for a larger ensemble of projections to properly estimate the impacts of climate change on water resources in the catchment and on the other hand the high uncertainty associated with climate projections for the West African region. A water-energy budget analysis provides further insight into the behavior of the catchment.

\section{Introduction}

Development of adaptation strategies to deal with potential impacts of climate change on hydrological systems is a considerable challenge for water resources management (Muerth et al., 2013; Piani et al., 2010). Besides being highly exposed to climate change, the West African region presents a low adaptive capacity (IPCC, 2014). Projections for the late 21st century suggest severe consequences of climate change for water resources for the region. This includes an increased risk of water stress and flood (Sylla et al., 2015; Oyerinde et al., 2014) and significant change in river discharge (Aich et al., 2014; Ardoin-Bardin et al., 2009; Mbaye et al., 2015).

Rising temperatures, commonly acknowledged by regional climate models (RCMs) and global climate models (GCMs), are expected to intensify the hydrological cycle due to an increased water holding capacity of the atmosphere, leading to an increased amount of renewable fresh- 
water resources (Piani et al., 2010). Another consequence of temperature increase ascertained by Piani et al. (2010) for some regions is the decrease in precipitation associated with the intensification of the seasonal cycle and the frequency of extreme events. These opposite trends imply that high uncertainties are associated with predicted rising temperatures' impact on the hydrological cycle for some regions (Salack et al., 2015).

Confidence in RCMs and GCMs over West Africa relies on their ability to simulate the West African monsoon (WAM) precipitation (Klein et al., 2015). However, simulating the WAM remains challenging for both RCMs and GCMs (Cook, 2008; Druyan et al., 2009; Paeth et al., 2011; Ruti et al., 2011), as each RCM and GCM produces a version of the WAM, but with some distortion of structure and/or timing. Some GCMs (e.g., CSIRO, GISS_ER, ECHAM5, CCSM) do not generate the WAM at all (Cook and Vizy, 2006). Part of this divergence is related to (i) imperfect characterization of tropical precipitation systems; (ii) uncertain future greenhouse gas forcing; (iii) scarcity of observations over West Africa; and (iv) natural climate variability (Cook and Vizy, 2006; Foley, 2010). The hydrological climate change signal is therefore unclear for the region. Several authors (Kasei, 2009; Paeth et al., 2011; Salack et al., 2015) observed diverging precipitation signals among models. Moreover, several models fail to accurately reproduce the historical rainfall onset, maxima, pattern, and amount of the region (Nikulin et al., 2012; Ardoin-Bardin et al., 2009).

Despite significant advances, outputs of GCMs and RCMs are still characterized by biases that challenge their direct use in climate change impact assessment (Ehret et al., 2012). Indeed, unless the precipitation from climate models is bias corrected, results from hydrological simulations are often reported to be unrealistic and may lead to incorrect impact assessments (Johnson and Sharma, 2015; Teutschbein and Seibert, 2012; Ahmed et al., 2013). However, correction of climate model based simulation results does not ensure physical consistency (Muerth et al., 2013) and may affect the signal of climate change for specific regions as reported by Hagemann et al. (2011). Consequently, simulated hydrological variables using bias corrected data need to be explored in climate change impact assessment.

There is essential consensus on the necessity of performing multi-(climate)-model assessments to estimate the response of the West African climate to global change (Sylla et al., 2015). Accordingly, several studies (e.g., Chen et al., 2013; Zhang et al., 2011) emphasize the importance of using multiple climate models to account for uncertainty when assessing climate change impacts on water resources. Taking advantage of the results of the COordinated Regional climate Downscaling Experiment (CORDEX-Africa) project, this study evaluates potential climate change impacts on water resources using an ensemble of six RCMs-GCMs in the Dano catchment in Burkina Faso. The catchment experiences seasonally limited water availability, and like other catch- ments of the region, it has experienced the severe droughts of the 1970s (Kasei et al., 2009) which resulted in a decline of discharge in many West African catchments.

A few studies have already investigated the impacts of projected climate change on water resources in West Africa (see Roudier et al., 2014, for a review). Many of these studies have used an approach based on hydrological models driven by a single RCM or GCM dataset (e.g., Mbaye et al., 2015; Cornelissen et al., 2013; Bossa et al., 2012, 2014). Therefore, uncertainty related to the choice of the climate model was not explicitly evaluated. However, other studies have used multi-climate model datasets (Kasei, 2009; Ruelland et al., 2012, Aich et al., 2016); most of these studies have resulted in a diverging projected hydrological change signal. Climate model outputs have often been bias corrected to fit the historical climate variables and then used as input for hydrological models, but few have investigated the necessity of performing such corrections in detecting the signal of future climate change impacts on water resources.

The current study aims to investigate the future climate change impacts on the hydrology of the Dano catchment in Burkina Faso, thus contributing to the management of water resources in the region. Besides the small scale of the catchment that implies addressing scale issues, the novelty of the study includes a water-energy budget analysis. Specifically, it has the following objectives: (i) evaluate the historical runs of six RCMs-GCMs at the catchment scale; (ii) analyze the climate change signal for the future period of 2021-2050 compared to the reference period of 1971-2000; (iii) evaluate the ability of the climate models to reproduce the historical discharge; (iv) assess the impacts of climate change on the hydrology of the catchment by the middle of the 21 st century; and (v) perform an ecohydrological analysis of the catchment under climate change.

\section{Materials and methods}

\subsection{Study area}

The study was carried out in the Dano catchment covering a total area of $195 \mathrm{~km}^{2}$ in the Ioba province of southwestern Burkina Faso (Fig. 1). The catchment is one of the study areas of the WASCAL project (West African Science Service Center on Climate Change and Adapted Land Use, http://www.wascal.org), whose main target is to increase the resilience of human and environmental systems to climate change.

The major land uses in the catchment include shifting cultivation, which accounts for one-third of the catchment area; natural vegetation albeit converted into agricultural and fallow lands forms part of the Sudanian region characterized by wooded, scrubby savannah and abundant annual grasses. Sorghum (Sorghum bicolor), millet (Pennisetum glaucum), cotton (Gossypium hirsutum), maize (Zea mays), cowpeas 


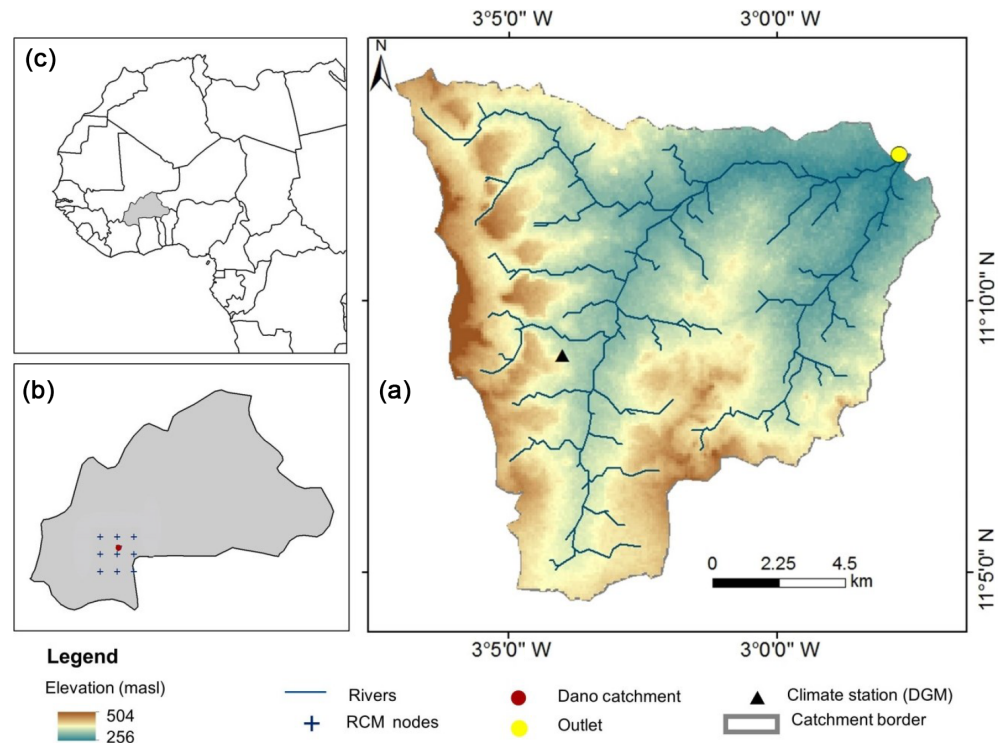

Figure 1. Location map: (a) Dano catchment, (b) its location in Burkina Faso, and (c) in West Africa. (b) RCM domain used in the study.

(Vigna unguiculata), and groundnut (Arachidis hypogaea) are the major crops cultivated in the catchment.

The catchment is characterized by a flat landscape with a mean slope of $2.9 \%$ and mean altitude of $295 \mathrm{~m}$ a.s.l. (above sea level). According to Schmengler (2011), a mean annual temperature of $28.6^{\circ} \mathrm{C}$ was recorded, while mean annual rainfall ranged from $800 \mathrm{~mm}$ to $1200 \mathrm{~m}$ for the period of 1951-2005. The catchment receives monsoonal rains with a dry season occurring in the months of November to April, with the wet season being experienced in the months of July to September. This kind of rainfall pattern limits water availability, especially in the dry season; hence, communities in the catchment are vulnerable to water scarcity since they heavily rely on surface water.

Plinthosol characterized by a plinthite subsurface layer in the upper first meter of the soil profile accounts for $73.1 \%$ of the soil types in the catchment; other soil types found within the catchment include gleysol, cambisol, lixisol, leptosol, and stagnosol (WRB, 2006).

\subsection{Climate data}

Observed mean daily temperature and daily precipitation used in the study were collected from the national meteorological service of Burkina Faso (DGM). The dataset covers the reference period of 1971-2000. Although the national observation network includes several rainfall gauges and synoptic stations, solely the data of the Dano station were used as it is located in the study area.

An ensemble of six RCM-GCM datasets is exploited in the study (Table 1). The RCM-GCM simulations were performed in the framework of the CORDEX-Africa project. The datasets were produced by three RCM groups (CCLM:
Table 1. RCM-GCM products and the corresponding label used in the study.

\begin{tabular}{llll}
\hline RCM & Driving GCM & $\begin{array}{l}\text { RCM center/ } \\
\text { institute }\end{array}$ & $\begin{array}{l}\text { Label used in the } \\
\text { study }\end{array}$ \\
\hline CCLM48 & CNRM-CM5 & CCLMcom & CCLM-CNRM \\
CCLM48 & EC-EARTH & CCLMcom & CCLM-EARTH \\
CCLM48 & ESM-LR & CCLMcom & CCLM-ESM \\
HIRHAM5 & NorESM1-M & DMI & HIRHAM-NorESM \\
HIRHAM5 & EC-EARTH & DMI & HIRHAM-EARTH \\
RACMO22 & EC-EARTH & KNMI & RAMCO-EARTH \\
\hline
\end{tabular}

Climate Limited-area Modelling Community, Germany; RACMO22: Royal Netherlands Meteorological Institute, Netherlands; HIRHAM5: Alfred Wegener Institute, Germany) using the boundary conditions of four GCMs (CNRMCM5, EC-EARTH, ESM-LR, NorESM-M). Each dataset consists of historical runs and projections based on emission scenarios RCP4.5 and RCP8.5 (Moss et al., 2010). The retrieved data (precipitation and temperature) range from 1971 to 2000 for the historical runs and from 2021 to 2050 for the RCPs.

An extent of 9 nodes $(3 \times 3$, which is the RCM models' resolution degraded by a factor of 3 ) of the African CORDEX domain, surrounding the catchment, was delineated to simulate the catchment's climate (Fig. 1b). The areal mean of the 9 nodes was used to evaluate the simulated precipitation against the observations at the Dano station (the reference station). The climate variables (historical and projected) of the extent of 9 nodes were used as inputs for the hydrological simulation model as well.

Due to the discrepancy between the RCM-GCM data resolution $\left(0.44^{\circ}\right.$, about $\left.50 \mathrm{~km} \times 50 \mathrm{~km}\right)$ and the hydrological 


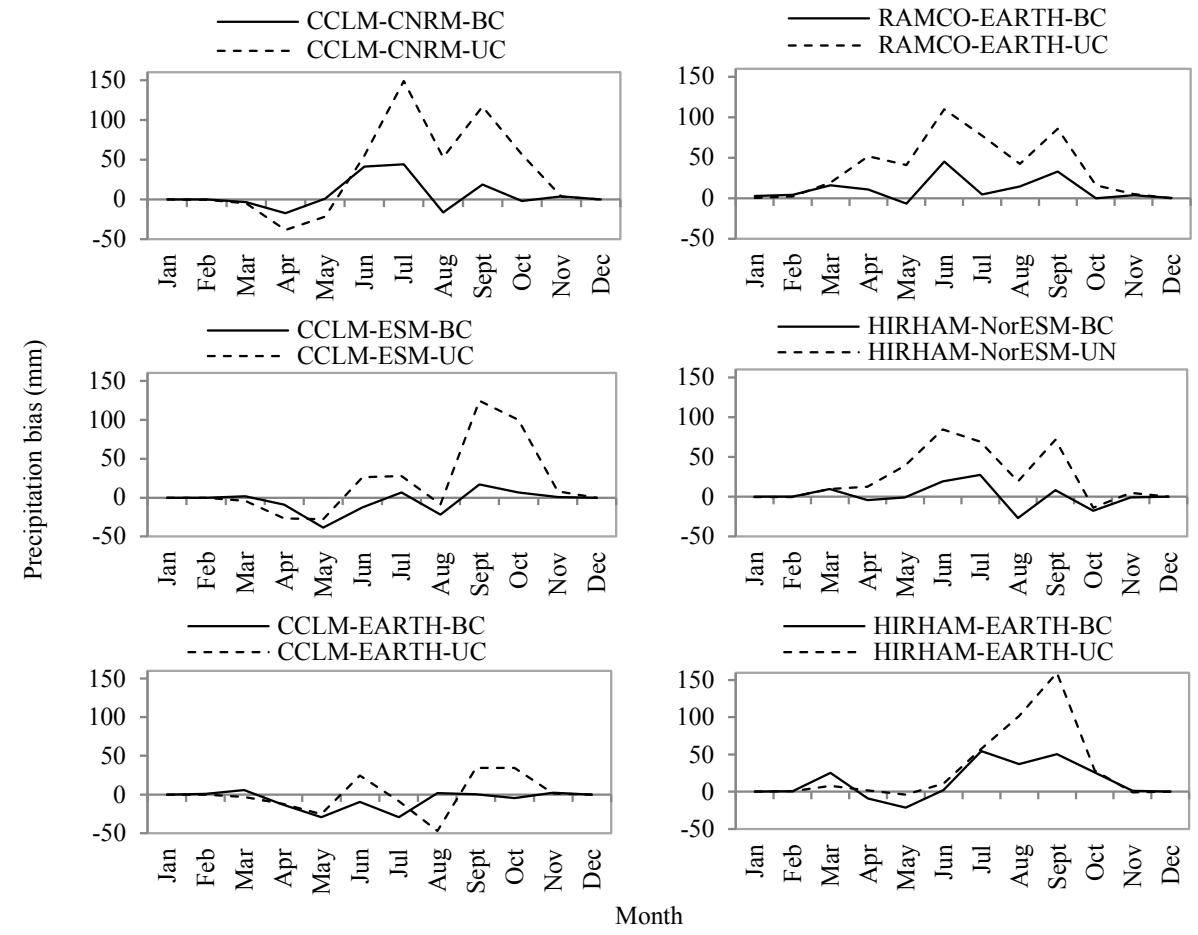

Figure 2. Absolute precipitation bias (corrected and not corrected) for the model ensemble compared to the observed data for the period of 1991-2000. The transfer functions were calibrated for the period 1971-1990.

modeling domain (about $18 \mathrm{~km} \times 11 \mathrm{~km}$ ) the data of each node were separately used as climate input for the hydrological simulation model. Therefore, for each period (historical and projected scenarios) nine simulations corresponding to the nine nodes are performed per RCM-GCM. The monthly water balance for each RCM-GCM is then calculated as the arithmetic mean.

\subsection{Bias correction of precipitation data}

The RCM-GCM ensemble was evaluated to get an estimate of the historical simulated variables for the catchment by comparing RCM-GCM based simulations of historical climate variables to the observations provided by the National Meteorological Service (DGM). As presented in Sect. 3.1, whereas temperature simulated by the models' ensemble encompassed the observed temperature with moderate deviation, precipitation simulated by individual RCMs-GCMs exhibited biases such as overestimation of annual precipitation as well as misrepresentation of the timing of the rainy season. A precipitation bias correction was therefore applied to the six RCMs-GCMs following the non-parametric quantile mapping using the empirical quantiles method (Gudmundsson et al., 2012). For each member, transfer functions (TFs) were derived using observed and modeled precipitation for the period of 1971-2000; afterwards the transfer functions were applied to the projected climate scenarios (period 20212050).
However, a consistent application of bias correction is subject to numerous hypotheses that need to be fulfilled, at the risk of altering the climate change signal (Muerth et al., 2013; Ehret et al., 2012; Hagemann et al., 2011). This includes the hypotheses of reliability, effectiveness, time invariance or stationarity, completeness, etc. (a complete discussion of these hypotheses is provided by Ehret et al. (2012)). Precipitation in the Dano region is characterized by a strong decadal variability and a non-stationary annual behavior (Oyerinde et al., 2014; Karambiri et al., 2011; Waongo, 2015), which implies that a TF derived from a short period (e.g., a decade) does not fulfill the time invariant hypothesis. Similarly, a TF derived from a short period precludes the hypothesis of completeness and is likely not to be suitable for application to a period that does not overlap the derivation period as TFs are likely to change from one period to another (Piani et al., 2010).

A cross-validation approach (e.g., Lafon et al., 2013; Teutschbein and Seibert, 2013) using the periods of 19711990 and 1991-2000 for calibration and verification, respectively, showed that for the climate model ensemble biases in precipitation are in general reduced by the bias correction method (Fig. 2). However, due to the mentioned decadal signal that characterizes precipitation variability in the region, considerable deviations between bias corrected and observed precipitation (up to $40 \mathrm{~mm} \mathrm{month}^{-1}$ ) are still noticeable. Therefore, a consistent application of bias correction 
Table 2. Selected submodels and algorithms of WaSiM.

\begin{tabular}{ll}
\hline Submodel & Algorithm \\
\hline Potential evapotranspiration & Hamon (based on Federer and Lash, 1983) \\
Actual evapotranspiration (ET) & Suction-dependent reduction according to Feddes et al. (1978) \\
Interception & Leaf area index dependent (bucket approach) \\
Infiltration & Based on saturated hydraulic conductivity, soil water content, and rainfall (Schulla, 2015) \\
Unsaturated soil zone & Richard's equation parameterized based on van Genuchten (1980) parameterization of the water retention curve \\
Discharge routing & Kinematic wave using the Manning-Strickler equation \\
\hline
\end{tabular}

in the context of the current impact study implies that both results achieved with bias corrected and non bias corrected climate inputs are provided as recommended by Ehret et al. (2012), to guarantee that the climate change signal is not altered by the bias correction approach under changing conditions. To get a better approximation of the completeness hypothesis, the TFs for each climate model were derived using all the historical climate data available at the reference station (period 1971-2000).

\subsection{Hydrological modeling}

Observed and RCM-GCM based (historical runs and projections) data were used as climate input for the Richards equation based version 9.05.04 of the Water flow and balance Simulation Model (WaSiM) (Schulla, 2015). WaSiM is a deterministic and spatially distributed model, which uses mainly physically based approaches to describe hydrological processes. The model configuration as applied in this study is shown in Table 2. Schulla (2015) gives more details of the model structure and processes in the Model Description Manual.

A previous study confirmed the suitability of WaSiM to model the hydrology of the Dano catchment. Details of the model setup and parameterization are available in that study (Yira et al., 2016). Briefly summarized, the model was calibrated and validated using observed discharge for the period of 2011-2014, daily time steps, and a regular raster-cell size of $90 \mathrm{~m}$. Latin hypercube sampling (LHS) was used to identify and optimize sensitive parameters (drainage density, storage coefficient for surface runoff, and storage coefficient for interflow) with the sum of the squared error set as an objective function. Following the LHS, several model parameterizations lead to equally good model quality measures. Out of these good parameter sets, the one scoring the highest sum of the Pearson product-moment correlation coefficient $\left(r^{2}\right)$, Nash-Sutcliffe efficiency (NSE, Nash and Sutcliffe, 1970), and Kling-Gupta efficiency (KGE, Gupta et al., 2009; Kling et al., 2012) were used as the best parameter set.

In the absence of long-term observation discharge for the catchment, the reliability of the model parameters in time could not be assessed in a classical way. Therefore, a soft validation approach was adopted. The approach consisted in determining, based on the Standardized Precipitation In- dex, whether the calibration/validation years represented normal years in the catchment (considering the historical period of 1990 to 2014). This evaluation showed that both calibration and validation periods are normal and reflect the annual rainfall pattern in the catchment for the period 19902014 (Fig. 1_supplementary materials in Yira et al., 2016, shows this evaluation). Therefore, the model parameters for the catchment are expected to be reliable for a long period.

In addition to the validation using the discharge, the model was further validated against soil moisture under the dominating soil type and groundwater level recorded by four piezometers. Minimum values of 0.7 for NSE, KGE, and $r^{2}$ were achieved during the calibration and validation using observed discharge. $r^{2}$ was higher than 0.6 for soil moisture and groundwater level. Therefore, no further model calibration was done in the current study.

Discharge simulated with RCM-GCM historical runs (bias corrected and non bias corrected) was compared to the discharge obtained with observed historical climate data. These comparison runs showed that bias correction was necessary for RCM-GCM based simulations to reproduce the historical discharge regime. To integrate the potential effect of bias correction on climate change signal as discussed in Sect. 2.3 and raised by different authors (e.g., Muerth et al., 2013; Ehret et al., 2012; Hagemann et al., 2011), the hydrological model was run with both bias corrected and non bias corrected climate inputs for the climate model ensemble.

No hydrologic observations (discharge, soil moisture, and groundwater level) are available for the reference period (1971-2000) in the catchment. The expected climate change for an RCM-GCM is therefore expressed as the relative difference between simulated hydrological variables under the reference period (1971-2000) and future pe$\operatorname{riod}(2021-2050)$.

\subsection{Ecohydrologic analysis}

A concept of water-energy budget (Tomer and Schilling, 2009; Milne et al., 2002) was applied to estimate the effectiveness of water and energy use by the catchment as it undergoes climate change. While experiencing climate change, a trend towards the optimization of total unused water- $P_{\mathrm{ex}}(1)$ and energy $-E_{\mathrm{ex}}(2)$ existing in the environment is usually observed. Plotting $P_{\mathrm{ex}}$ against $E_{\mathrm{ex}}$ allows for determination 
of the ecohydrologic status of the catchment. The climate change signal can therefore be detected by the shift in this status. The direction of the shift indicates whether the catchment experienced water stress or increased humidity. The approach was used to test its validity in analyzing the interplay between temperature increase and precipitation change as projected by the RCM-GCM ensemble.

$P_{\mathrm{ex}}=\frac{\left(P-\mathrm{ET}_{\mathrm{a}}\right)}{P}$,

$E_{\mathrm{ex}}=\frac{\left(\mathrm{ET}_{\mathrm{p}}-\mathrm{ET}_{\mathrm{a}}\right)}{\mathrm{ET}_{\mathrm{p}}}$,

where $P_{\mathrm{ex}}$ is the unused water; $E_{\mathrm{ex}}$ is the unused energy; $P$ is the precipitation; $\mathrm{ET}_{\mathrm{a}}$ is the actual evapotranspiration; and $\mathrm{ET}_{\mathrm{p}}$ is the potential evapotranspiration.

\subsection{Assessment criteria}

A set of evaluation measures was used to analyze the RCMGCM historical runs, to assess model performance and to estimate the effects of different climate scenarios on hydrological variables.

i. $P$ factor: measures the percentage of observed climate data covered by the RCM-GCM ensemble historical runs.

ii. The $R$ factor, calculated following Eq. (3), indicates for an observation series how wide the range between minimum RCM-GCM and maximum RCM-GCM for precipitation and temperature is, compared to the observation:

$R$ factor $(\operatorname{Var})=\frac{1}{n \sigma_{\operatorname{Var}_{\text {obs }}}} \sum_{l=1}^{n}\left(\operatorname{Var}_{\mathrm{Si}_{\text {max }}}-\operatorname{Var}_{\mathrm{Si}_{\text {min }}}\right)$,

where Var is the climate variable (e.g., precipitation); $n$ is the observation data points; $\sigma$ is the standard deviation; obs is the observation; $\mathrm{Si}_{\min }$ is the minimum value of the RCM-GCM ensemble; and $\mathrm{Si}_{\max }$ is the maximum value of the RCM-GCM ensemble.

iii. The normalized root-mean-square deviation (NRMSD): expresses the deviation of each RCM-GCM based precipitation and temperature from the observations.

iv. The Pearson product-moment correlation coefficient $\left(r^{2}\right)$, the percent bias (PBIAS), the Nash-Sutcliffe efficiency (NSE) (Nash and Sutcliffe, 1970), and the Kling-Gupta efficiency (KGE) (Gupta et al., 2009; Kling et al., 2012) assess the RCM-GCM based discharge simulations' ability to reproduce discharge computed using observed climate data.

v. The change signal $(\Delta)$ in climate and hydrological variables (precipitation, temperature, and discharge) expresses the difference between projected and historical values (Eq. 5); and

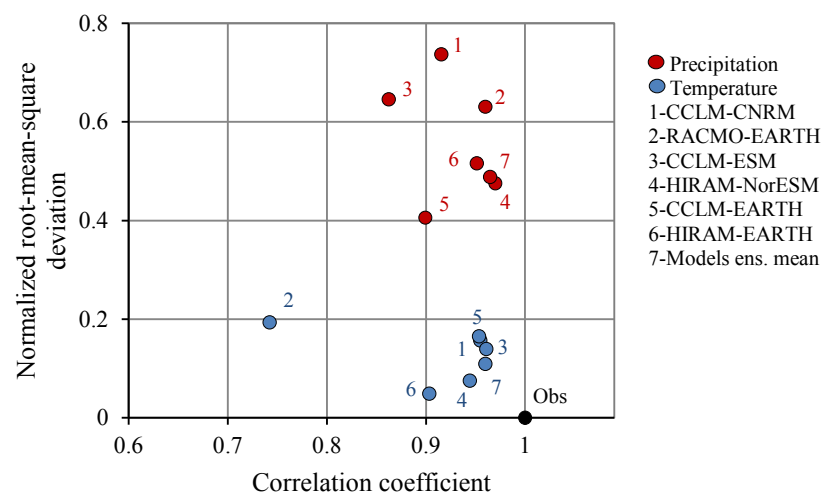

Figure 3. Statistics of RCM-GCM based precipitation and temperature compared to observations (Obs) for the reference period (19712000). Climate model data are not bias corrected. Statistics are computed based on average monthly values.

$\Delta \operatorname{Var}=\frac{\left(\operatorname{Var}_{P_{1}}-\operatorname{Var}_{R e f}\right) \times 100}{\operatorname{Var}_{\text {Ref }}}$,

where $\Delta$ Var is the change signal for the evaluated variable (e.g., discharge); $\operatorname{Var}_{P_{10}}$ is the projected value of the variable (period of 2021-2050 under RCP4.5 and RCP8.5); and $\operatorname{Var}_{\text {Ref }}$ is the reference value of the variable (period of 1971-2000).

vi. The Wilcoxon (1945) rank-sum test was used to compare the discharge change signal with bias corrected and non bias corrected precipitation data following Muerth et al. (2013). The test evaluated the null hypothesis "discharge change signal under bias corrected data equals discharge change signal under non bias corrected data". The rejection of the test at $5 \%$ implies that future discharge change under bias correction and no bias correction are significantly different. If the test is not rejected, both discharge change under bias correction and change under non bias correction yield the same result, and thus bias correction does not alter the climate change signal on projected discharge.

\section{Results}

\subsection{Historical runs analysis}

The comparison between RCM-GCM historical runs and observations for temperature and precipitation is done for the reference period of 1971-2000 for average monthly values. The correlation coefficient is plotted against the NRMSD (Fig. 3) for a cross-comparison between RCMs-GCMs in order to assess the relative ability of each RCM-GCM to represent historical climate conditions in the catchment. The correlation coefficient for the RCM-GCM ensemble is in general higher than 0.7 for both precipitation and temperature. 


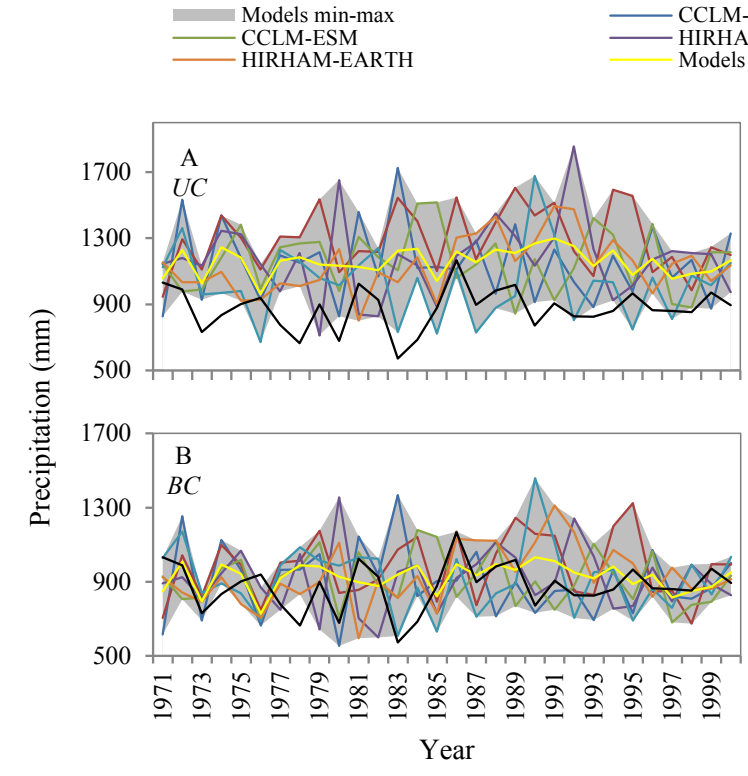

CCLM-EARTH - DGM/observed
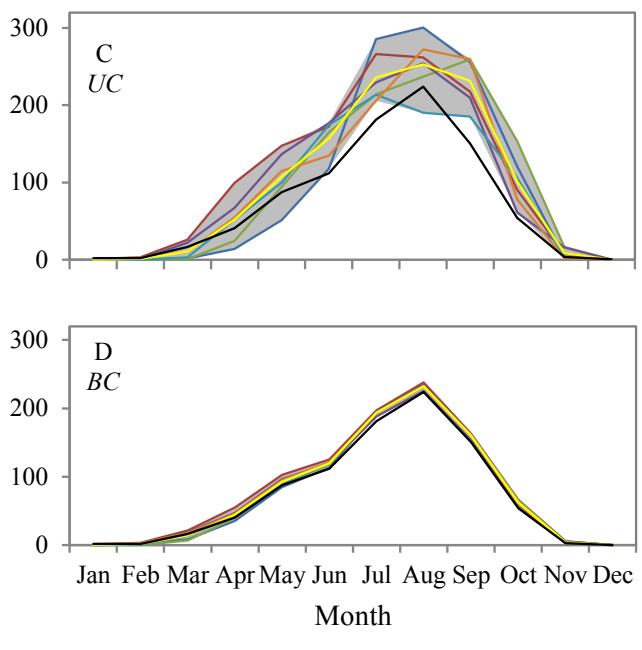

Figure 4. Historical mean annual (a, b) and mean monthly $(\mathbf{c}, \mathbf{d})$ precipitation. UC refers to non bias corrected, BC to bias corrected. The $P$ factor equals 50, 80, 50, and $50 \%$ for (a)-(d), respectively. The $R$ factor equals 4.3, 3.2, 0.6, and 0.11 for (a)-(d), respectively.

The highest coefficients (0.96) are scored by CCLM-ESM for temperature and HIRAM-NorESM for precipitation. The RCM-GCM ensemble mean outscores five members of the RCM-GCM ensemble with regard to temperature and precipitation (Fig. 3).

The RCM-GCM ensemble shows a clear deviation from observed precipitation compared to temperature (Fig. 3). HIRAM-EARTH and CCLM-EARTH present the lowest deviation for temperature and precipitation, respectively. The RCM-GCM ensemble mean outscores four out of six RCMs-GCMs for temperature and precipitation with regard to the deviation from observed data.

Figure $4 \mathrm{a}$ and $\mathrm{b}$ show a trend towards an overestimation of annual precipitation throughout the reference period for the RCM-GCM ensemble when precipitation data are not bias corrected (UC). Although the RCM-GCM ensemble presents a large dispersion $(R$ factor $=4.3)$, only $50 \%$ ( $P$ factor $=0.5$ ) of observed precipitation is covered by the RCM-GCM ensemble. After bias correction (BC), the RCM-GCM ensemble agrees in general with the observed precipitation $(P$ factor $=0.8)$; moreover, the dispersion of climate model based precipitation decreases $(R$ factor $=3.2)$.

The mean annual precipitation pattern is in general well captured by all RCMs-GCMs (Fig. 4c and d). However, the climate models' ensemble, when not bias corrected, covers only $50 \%$ of monthly precipitation despite a large dispersion (Fig. 4c). After bias correction, the agreement between RCM-GCM based precipitation and observation is considerably improved (Fig. 4d), and the uncertainty band of the climate model is considerably reduced $(R$ factor $=0.1)$. How-

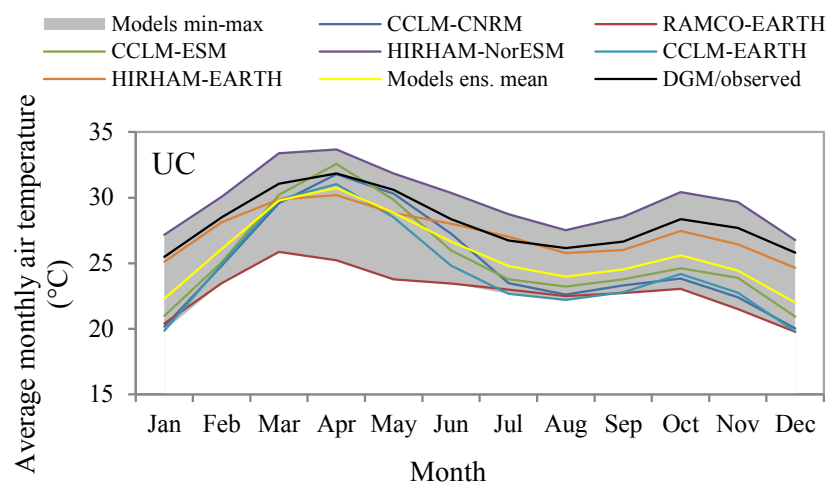

Figure 5. Monthly air temperature derived from climate models and observations for the reference period (1971-2000). Data are not bias corrected. $P$ factor $=100 \%$ and $R$ factor $=8.2$.

ever, a slight positive bias is still presented by the climate models' ensemble.

Figure 5 shows that the RCM-GCM ensemble fully captures the annual temperature pattern $(P$ factor $=100 \%)$. However, a gap of up to $-4{ }^{\circ} \mathrm{C}$ between some climate models and observations is noted. This translates into an $R$ factor reaching 8.2. On average, RACMO-EARTH shows an underestimation of temperatures throughout the year, whereas HIRAM-NorESM indicates an opposite trend.

\subsection{Climate change signal}

The RCM-GCM ensemble exhibits a mixed annual precipitation change signal between the reference period (19712000) and future period (2021-2050) (Table 3). CCLM- 

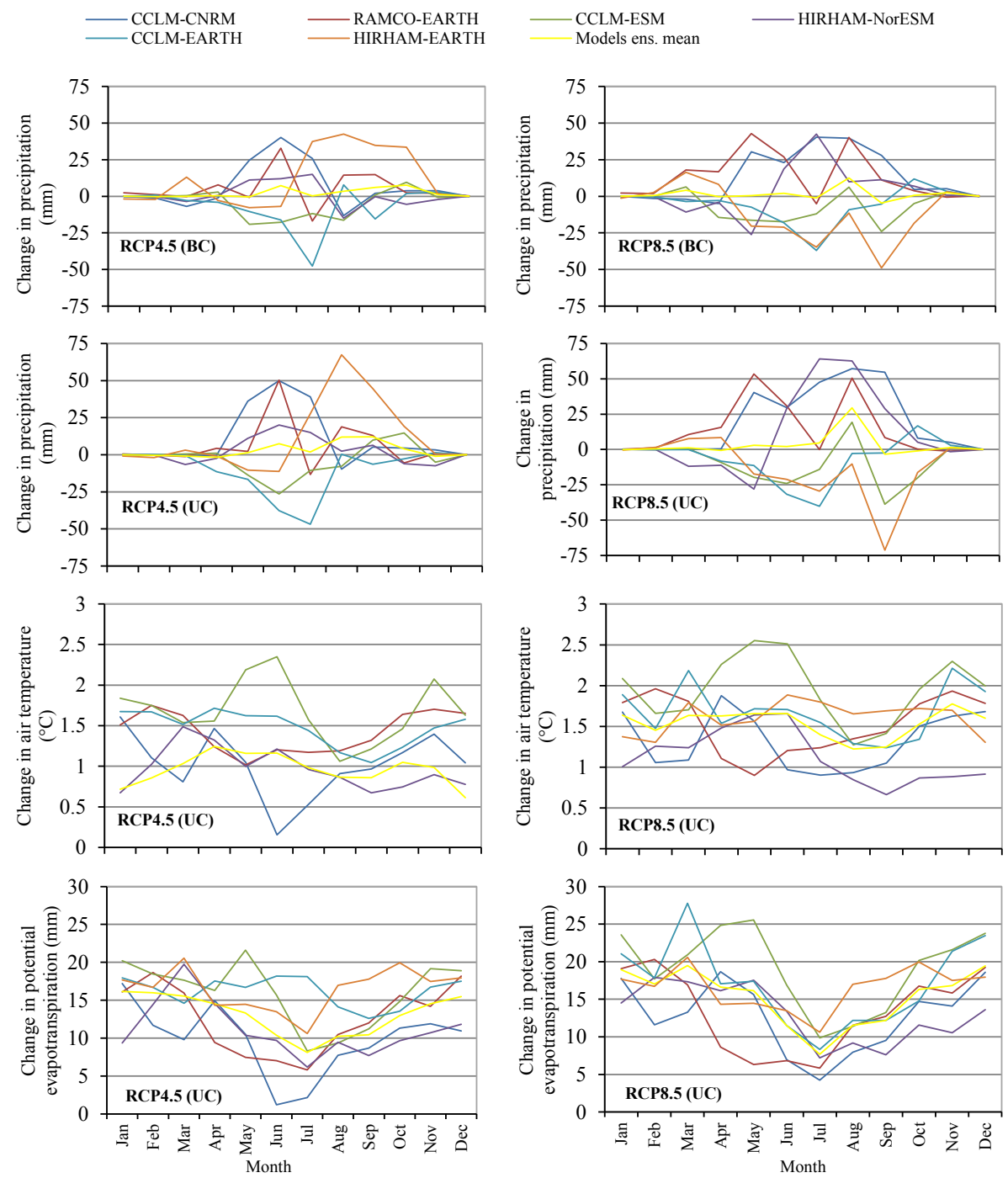

Figure 6. Climate change signal of precipitation, air temperature, and evapotranspiration between the reference (1971-2000) and future (2021-20150) periods under emission scenarios RCP4.5 and RCP8.5. BC is bias corrected and UC refers to non bias corrected.

CNRM, RAMCO-EARTH, and HIRHAM-NorESM project a precipitation increase of about 2.5 to $21 \%$, whereas CCLM-ESM and CCLM-EARTH indicate a decrease of 3 to $11 \%$. Bias correction has a minor impact on these signals, as the magnitude of projected precipitation increase ranges from 1 to $18 \%$ and the decrease is around $5-13 \%$ after bias correction.

A much more complex intra-annual precipitation change signal is projected by the climate models' ensemble (Fig. 6). CCLM-CNRM and HIRHAM-NorESM, which projected increased annual precipitation, are characterized by increased rainfall from May to June followed by decreased rainfall in August. RAMCO-EARTH shows increased rainfall throughout the season except in July. The decrease in annual precipitation projected by CCLM-ESM and CCLM-EARTH is consistent throughout the entire season. The climate model en- semble consistently projects a mean monthly temperature increase of about 0.1 to $2.3^{\circ} \mathrm{C}$ under RCP 4.5 and 0.6 to $2.5^{\circ} \mathrm{C}$ under RCP8.5, leading to an increase in potential evapotranspiration for the climate models' ensemble.

\subsection{Historical discharge}

RCM-GCM ensemble based discharges are compared to discharge simulated using observed climate data to evaluate the climate models' ability to reproduce the historical discharge regime over the reference period (Fig. 7). Accordingly, performances $\left(r^{2}\right.$, NSE, KGE, and PBIAS) achieved by the climate models are presented in Table 4. Figure 7a shows good agreement between bias corrected climate model based discharge and observation based discharge, with a trend towards discharge overestimation for some climate models (RACMO-EARTH, CCLM-EARTH, and HIRAM-EARTH). 
Table 3. Projected rainfall change between the reference (1971-2000) and future (2021-2050) periods with bias corrected and non bias corrected RCM-GCM based simulations.

\begin{tabular}{|c|c|c|c|c|c|c|}
\hline \multirow[b]{2}{*}{ RCM-GCM } & \multicolumn{3}{|c|}{ Non bias corrected } & \multicolumn{3}{|c|}{ Bias corrected } \\
\hline & $\begin{array}{l}\text { Historical } \\
\text { precipitation } \\
(\mathrm{mm})\end{array}$ & $\begin{array}{r}\text { Precipitation } \\
\text { change RCP4.5 } \\
(\%)\end{array}$ & $\begin{array}{r}\text { Precipitation } \\
\text { change RCP8.5 } \\
(\%)\end{array}$ & $\begin{array}{l}\text { Historical } \\
\text { precipitation } \\
(\mathrm{mm})\end{array}$ & $\begin{array}{r}\text { Precipitation } \\
\text { change RCP4.5 } \\
(\%)\end{array}$ & $\begin{array}{r}\text { Precipitation } \\
\text { change RCP8.5 } \\
(\%)\end{array}$ \\
\hline CCLM-CNRM & 1150 & +10.9 & +21.2 & 900 & +8.9 & +18.2 \\
\hline CCLM-EARTH & 1027 & -11.7 & -7.5 & 918 & -9.2 & -7.3 \\
\hline CCLM-ESM & 1165 & -3.3 & -9.0 & 912 & -5.7 & -8.2 \\
\hline HIRHAM-NorESM & 1173 & +2.8 & +11.7 & 912 & +1.3 & +5.5 \\
\hline HIRHAM-EARTH & 1135 & +12.1 & -13.0 & 934 & +15.1 & -13.4 \\
\hline RAMCO-EARTH & 1292 & +5.3 & +13.2 & 979 & +6.2 & +16.1 \\
\hline Models ens. mean & 1157 & +2.6 & +2.8 & 925 & +2.7 & +1.8 \\
\hline
\end{tabular}

Table 4. Performance of RCM-GCM based discharge compared to observation based discharge. Performance is calculated using mean monthly discharges for the period 1971-2000.

\begin{tabular}{|c|c|c|c|c|}
\hline Climate model & $r^{2}$ & NSE & KGE & PBIAS \\
\hline \multicolumn{5}{|c|}{ Bias corrected } \\
\hline CCLM-CNRM & 0.99 & 0.86 & 0.65 & 17 \\
\hline CCLM-EARTH & 0.97 & 0.82 & 0.59 & 22 \\
\hline CCLM-ESM & 0.97 & 0.87 & 0.68 & 14 \\
\hline HIRHAM-NorESM & 0.98 & 0.99 & 0.92 & -1 \\
\hline HIRHAM-EARTH & 0.98 & 0.95 & 0.78 & 5 \\
\hline RAMCO-EARTH & 0.94 & 0.65 & 0.50 & 27 \\
\hline \multicolumn{5}{|c|}{ Non bias corrected } \\
\hline CCLM-CNRM & 0.88 & -1.29 & -0.32 & 100 \\
\hline CCLM-EARTH & 0.84 & 0.43 & 0.20 & 50 \\
\hline CCLM-ESM & 0.71 & -1.41 & -0.36 & 105 \\
\hline HIRHAM-NorESM & 0.82 & -0.58 & -0.32 & 97 \\
\hline HIRHAM-EARTH & 0.71 & -0.80 & -0.33 & 97 \\
\hline RAMCO-EARTH & 0.89 & -2.60 & -0.87 & 148 \\
\hline
\end{tabular}

All climate models show satisfactory statistical quality measures after bias correction. Bias correction impact on simulated historical discharge is shown in Fig. 7b. Simulated discharge with non bias corrected data leads to a misrepresentation of the discharge regime (e.g., peak flow is shifted from August to September for CCLM-ESM and discharge is highly overestimated for all climate models). Moreover, poor quality measures are achieved by the climate model ensemble with non bias corrected data (Table 4).

\subsection{Discharge change}

Projected change in annual discharge for the period of 20212050 compared to the reference period is presented in Table 5. As for precipitation, a mixed annual discharge change signal is projected by the climate model ensemble. With bias corrected climate data, the following is projected: (i) a more

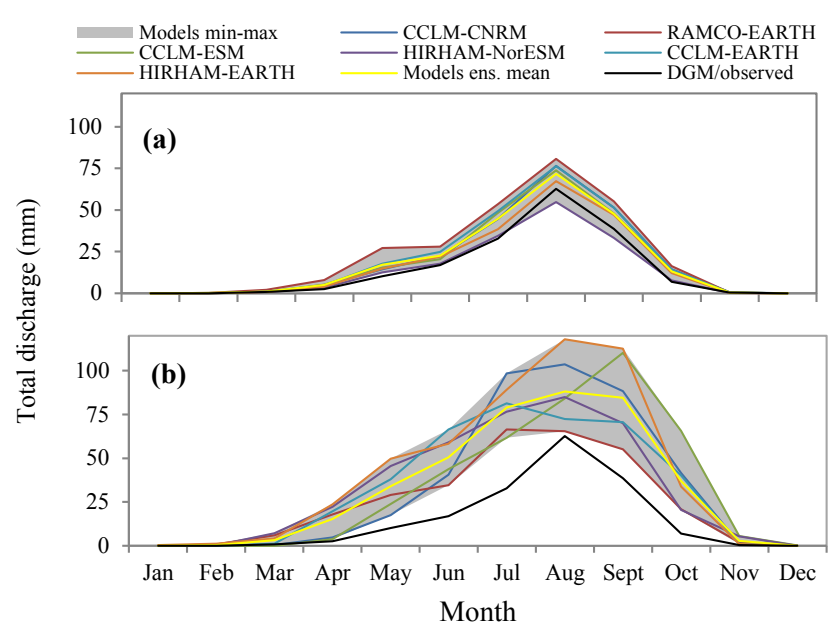

Figure 7. Historical RCM-GCM based discharge simulations and observation based discharge: (a) RCM rainfall is bias corrected, (b) RCM rainfall non bias corrected.

than $15 \%$ decrease in annual discharge, which is a consequence of relative decrease in precipitation and a consistent increase in potential evapotranspiration for CCLM-ESM, CCLM-EARTH, and HIRHAM-EARTH (RCP8.5); and (ii) a low to very high (3 to $50 \%$ ) increase in total discharge due to increased precipitation not counterbalanced by the evapotranspiration for CCLM-CNRM, RAMCO-EARTH, HIRHAM-NorESM, and HIRHAM-EARTH (RCP4.5). This divergence between climate models is reflected through a large amount of uncertainty associated with the projected annual discharge (Fig. 8). The projected intra-annual change in discharge (Fig. 9) is very similar to the precipitation change signal shown in Fig. 6. The discharge changes with non bias corrected climate data are similar in trend (with however differences in magnitude) compared to the changes observed with bias corrected data, which is consistent with changes in the climate signal induced by the bias correction. 


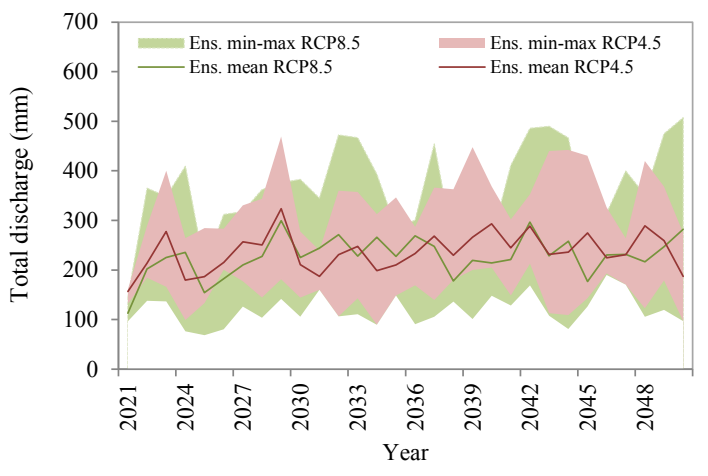

Figure 8. Projected annual discharge for the climate models' ensemble. Simulations are performed with bias corrected precipitation data.

The Wilcoxon (1945) rank-sum test, testing the significance of the difference between bias corrected and non bias corrected discharge change signals for the climate model ensemble, indicates that the signals are not different at a $p$-level equalling 0.05. A $p$-value of the Wilcoxon rank-sum test higher than 0.5 is required under both RCP4.5 and RCP8.5 to reject the null hypothesis $\left(H_{0}\right.$ : discharge change with bias corrected data $=$ discharge change with non bias corrected data). Hence, the bias correction impact on discharge change signal alteration can be considered negligible.

The sensitivity of the catchment discharge to precipitation and temperature change is tested by plotting, for each member of the climate models' ensemble, predicted precipitation, and temperature change against predicted discharge change. The result shows that change in total discharge cannot be strongly related to change in potential evapotranspiration (Fig. 10a). However, a high sensitivity of river discharge to precipitation change (Fig. 10b) is observed. Under scenario RCP4.5, an increase of $+5 \%$ in precipitation leads to an increase in discharge of about $+12.5 \%$, whereas a decreased precipitation on the same order leads to a decrease in discharge of $-13 \%$. The same simulations under RCP8.5 yield a $+8.3 \%$ discharge increase and a $-14.7 \%$ discharge decrease. Interestingly, under RCP8.5 and assuming comparable precipitation between reference and future periods, a discharge decrease of about $-3.2 \%$ should be expected (Fig. 10b).

\subsection{Ecohydrologic status}

The ecohydrologic status of the catchment for the reference period and future scenarios RCP4.5 and RCP8.5 is shown in Fig. 11 to illustrate the use of energy and water by the catchment while undergoing temperature increase and precipitation change. Moving left to right along the "Excess water $-P_{\text {ex }}$ " axis indicates that the environmental conditions in the catchment lead to an increase in discharge (CCLMCNRM, RAMCO-EARTH, and HIRHAM-NorESM). Re-
Table 5. Mean annual discharge change projected by the RCMGCM ensemble for the period 2021-2050 compared to the reference period 1971-2000.

\begin{tabular}{lcrc}
\hline Climate model & $\begin{array}{c}\text { Reference } \\
\text { discharge } \\
(\mathrm{mm})\end{array}$ & $\begin{array}{r}\text { Discharge } \\
\text { change } \\
\text { RCP4.5 } \\
(\%)\end{array}$ & $\begin{array}{c}\text { Discharge } \\
\text { change } \\
\text { RCP8.5 } \\
(\%)\end{array}$ \\
\hline & Bias corrected & & \\
\hline CCLM-CNRM & 232 & +16.4 & +40.5 \\
CCLM-EARTH & 242 & -22.7 & -19.0 \\
CCLM-ESM & 227 & -11.9 & -18.9 \\
HIRHAM-NorESM & 195 & +3.6 & +17.9 \\
HIRHAM-EARTH & 209 & +50.7 & -39.7 \\
RAMCO-EARTH & 273 & +6.6 & +27.1 \\
\hline & Non bias corrected & \\
\hline CCLM-CNRM & 397 & +18.4 & +39.5 \\
CCLM-EARTH & 298 & -29.5 & -18.5 \\
CCLM-ESM & 407 & -4.7 & -17.2 \\
HIRHAM-NorESM & 392 & +4.1 & +25.8 \\
HIRHAM-EARTH & 391 & +30.2 & -30.9 \\
RAMCO-EARTH & 492 & +6.7 & +24.8 \\
\hline
\end{tabular}

duction of discharge is experienced when moving the other way round (CCLM-ESM and CCLM-EARTH).

Moving upwards along "Excess evaporative demand $-E_{\text {ex }}$ " implies drier environmental conditions due to an increase in evaporative demand and soil water deficit. Except for HIRAM-EARTH, all the climate models project drier conditions (increase in Excess evaporative demand) under RCP4.5 as a result of an increased temperature not compensated for by the amount and/or timing of precipitation. Increased evaporative demand, with marginally aggravated drier conditions, is shown by CCLM-ESM, HIRAM-NorESM, CCLM-EARTH, and the RCM-GCM ensemble mean under RCP8.5.

The ecohydrologic status of the catchment, irrespective of climate model and emission scenario, projects a shift for the period of 2021-2050 compared to the reference period. Therefore, differences in climate conditions between the two periods influence the hydrology (discharge, evapotranspiration, precipitation) of the catchment.

\section{Discussion}

\subsection{Historical runs' analysis}

All GCMs and RCMs applied in this study have proved in previous works to fairly reproduce the climatology of West Africa (Cook and Vizy, 2006; Dosio et al., 2015; Gbobaniyi et al., 2014; Paeth et al., 2011). The RCM-GCM ensemble reasonably captures the annual cycle of temperatures, and following several authors (e.g., Buontempo et al., 2014; 


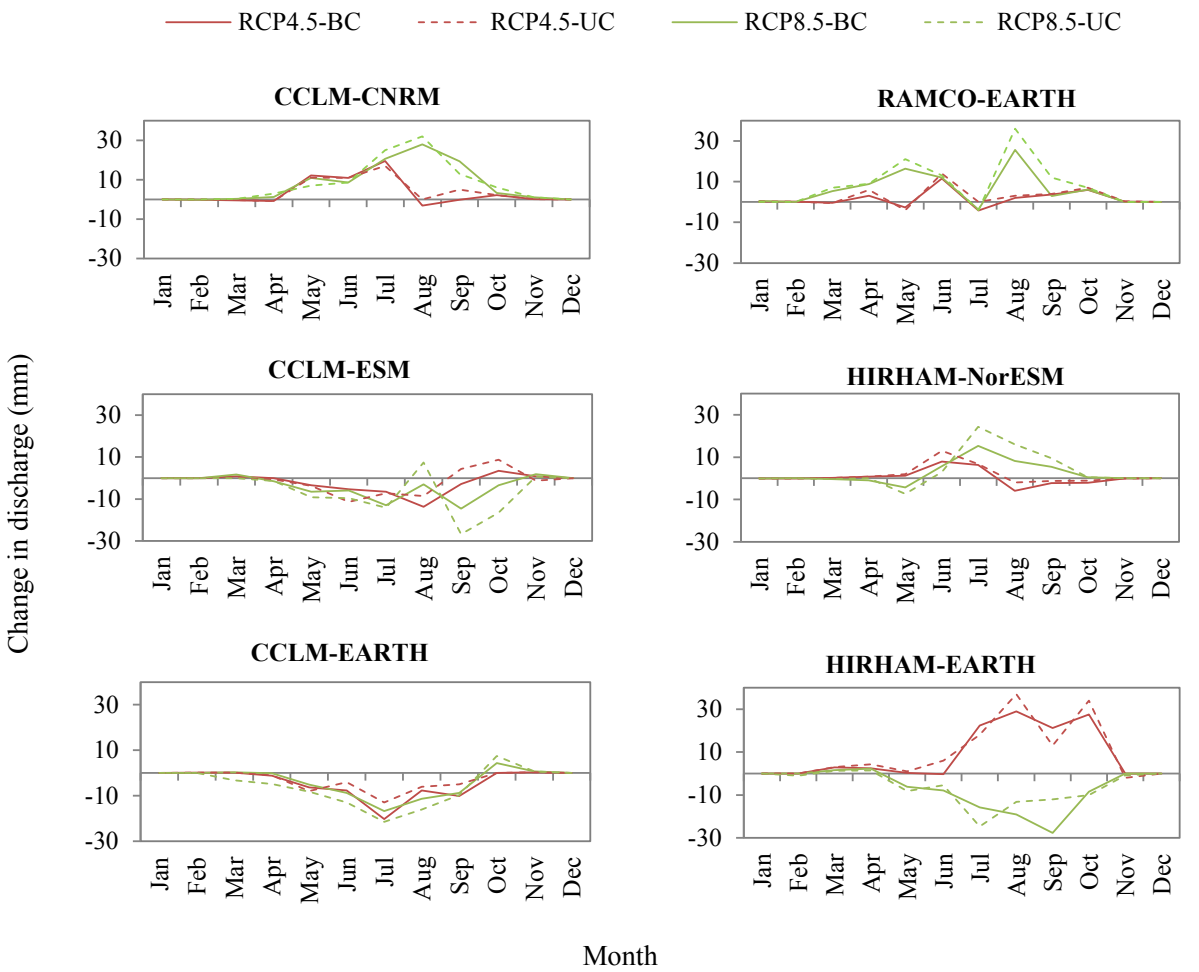

Figure 9. Monthly discharge change between the reference period (1971-2000) and the future period (2021-2050) under emission scenarios RCP4.5 and RCP8.5. BC and UC refer to bias corrected and non bias corrected, respectively.
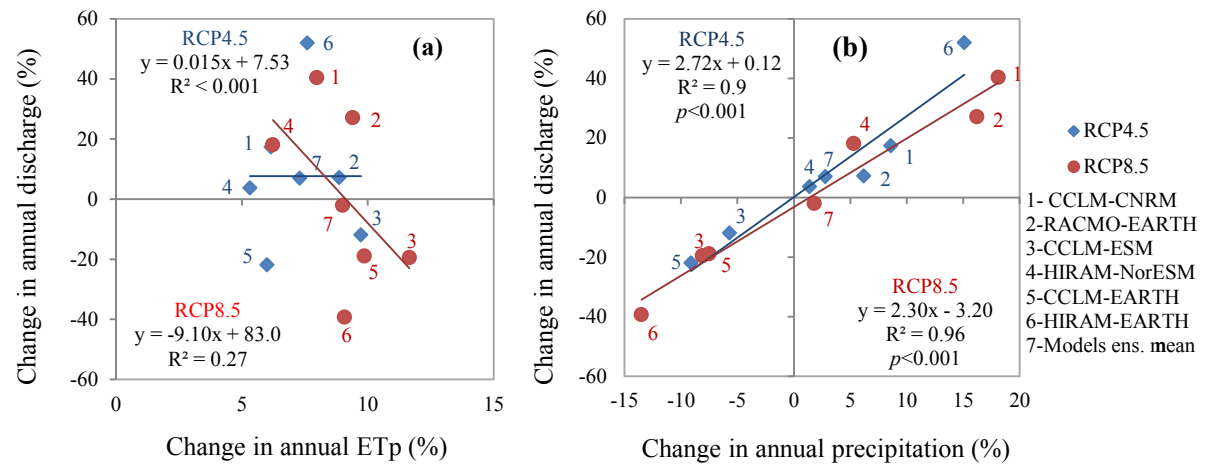

Figure 10. Change in the annual discharge as a response to potential evapotranspiration (a) and precipitation (b) change under emission scenarios RCP4.5 and RCP8.5. Projected precipitation, potential evapotranspiration, and discharge changes are calculated comparing period 1971-2000 to period 2021-2050.

Waongo et al., 2015) no bias correction was performed for this climate variable. The systematic positive bias and large deviation from observed precipitation exhibited by the climate models' ensemble in this study are also reported by several authors (Nikulin et al., 2012; Paeth et al., 2011) for the southern Sahel Zone. This deviation motivated the bias correction of precipitation. After correction, the positive bias is significantly reduced for all individual climate models and the improvement is clearly visible.

In general, the RCM-GCM ensemble mean outperforms individual climate models for both temperature and precip- itation. This is due to the fact that individual model errors of opposite sign cancel each other out (Nikulin et al., 2012; Paeth et al., 2011). However, the climate models' ensemble mean should not be considered an expected outcome (Nikulin et al., 2012). Rather, considering a large ensemble of climate models should be seen as necessary to properly perform future climate impact studies in the catchment (Gbobaniyi et al., 2014) and to assess the range of potential future hydrological status required for adaptation and management strategies. 


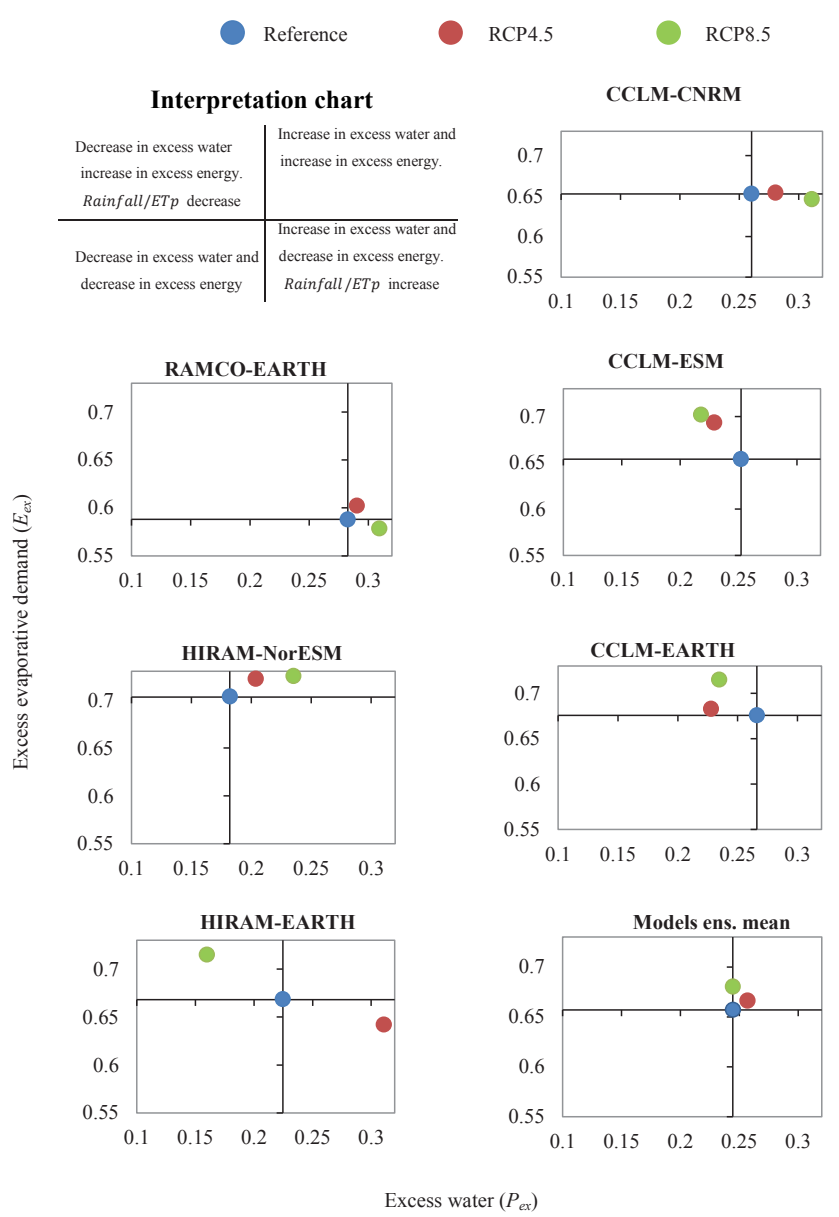

Figure 11. Plot of excess precipitation $\left(P_{\mathrm{ex}}\right)$ vs. evaporative demand $\left(E_{\mathrm{ex}}\right)$ for the reference period (1979-2000) and emission scenarios RCP4.5 and RCP8.5 (2021-2050) for the RCM-GCM ensemble. The shift in RCP dots compared to the reference period's dot indicates the effects of climate change on the catchment hydrology. $P_{\text {ex }}$ and $E_{\text {ex }}$ for each period are calculated from the annual average rainfall, potential evapotranspiration, and actual evapotranspiration.

\subsection{Climate change signal}

Compared to the period of 1971-2000, a clear temperature increase signal is projected for $2021-2050$ by the six members of the RCM-GCM ensemble in the catchment. This feature is common to all multi-model ensemble studies performed in the region (IPCC, 2014). It is further in line with the historical temperature change observed in the region as reported by Waongo (2015), who used the same observation dataset applied in the current study. He reported an average +0.31 and $+0.17^{\circ} \mathrm{C}$ decade $^{-1}$ increase for the minimum and maximum temperature, respectively, for the region considering the period of 1960-2010. However, the climate models' ensemble does not agree on the projected precipitation change signal as wetter (RAMCO-EARTH), drier (CCLMESM and CCLM-EARTH), as well as mixed (CCLM-
CNRM, HIRHAM-NorESM, and HIRAM-EARTH) trends are shown by the individual model. It is worth noting that the Dano catchment is located in a region where the Coupled Model Intercomparison Project Phase 5 (CMIP5) models showed divergent precipitation change for the mid-21st century (IPCC, 2014).

The precipitation change projected by CCLM-CNRM and HIRHAM-NorESM, wetter conditions associated with drought during specific months, is consistent with the change reported by Patricola and Cook (2009) for the West African region. They highlighted an increase in precipitation in general, but also noted drier June and July months. A similar result is achieved by Kunstmann et al. (2008) in the Volta Basin, albeit with a decrease in precipitation at the beginning of the rainy season in April.

Precipitation change projected by CCLM-ESM and CCLM-EARTH is consistent with the decrease in the JuneJuly-August season noted by Buontempo et al. (2014). A reduction in precipitation during the rainy season is also achieved with RegCM3, driven by ECHAM5 in the Niger River Basin (Oguntunde and Abiodun, 2012). Up to $20.3 \%$ reduction of precipitation in some months is projected, but an increased precipitation during the dry season is also expected.

A critical analysis of CCLM (by Dosio et al., 2015) showed that the model is significantly influenced by the driving GCM (including EC-Earth, ESM-LR, and CNRM-CM). Such an analysis was not found for RACMO and HIRAM. Overestimation of precipitation is a common feature of the RCM-GCM ensemble applied in this study, which could suggest that the RCMs inherit the bias from the GCM (Dosio et al., 2015). Consistently with Paeth et al. (2011), the relation between RCM trend and driving GCM cannot be observed in the current study as CCLM-EARTH and RACMOEARTH clearly show opposite trends although both are driven by EC-EARTH. Differences in projected trends are also highlighted by individual RCMs driven by different GCMs (e.g., CCLM-EARTH and CCLM-CNRM).

\subsection{Historical discharge}

Compared to the observation based simulation, non bias corrected RCM-GCM based discharge is characterized by an overestimation of annual discharge. This misrepresentation results from the positive precipitation bias presented by the climate models' ensemble. The bias correction significantly improves the ability of all members of the climate models' ensemble to reproduce the historical discharge regime. By comparing simulated discharge with bias corrected and non bias corrected precipitation data, it clearly appears that the bias correction methodology is effective with regard to both discharge regime and total discharge; thus, it increases the quality (correspondence between projection and observation) of the model (Murphy, 1993). However, a trend towards dis- 
charge overestimation was noticed after bias correction of precipitation. This could be related to

i. the relatively long period used for the bias correction (1971-2000). As noticed by Piani et al. (2010), fragmenting the correction period to decade and deriving several transfer functions can improve the bias correction result and further contribute to capturing the decadal rainfall change that characterizes the West African climate; and

ii. the fact that temperature was not bias corrected. This led to $\mathrm{ET}_{\mathrm{p}}$ values that vary from one RCM-GCM to another since $\mathrm{ET}_{\mathrm{p}}$ after Hamon is computed based on temperature values only (Table 2 ). As a result, a relatively large range of potential evapotranspiration is observed for the climate models as an ensemble (Table 6).

In view of the general good simulation of historical discharge for the climate models' ensemble, it is worth noting that running the hydrological model with simulated climate data of one node at a time (Sect. 2.2) has reasonably bridged the discrepancy between RCM-GCM data resolution and the hydrological modeling domain (see Fig. S1 of the Supplement for the hydrological spread of the 9-node approach and Fig. $\mathrm{S} 2$ for the difference in precipitation between the 9 -node approach and the standard $3 \times 3$-node average approach). Therefore, the approach can be considered eligible for climate change impact assessment for small-scale catchments in which interpolation methods create issues related to the representation of climate variables (particularly precipitation). However, besides regional climate specificities, its reliability might depend on the extent of the RCM domain used to simulate a given catchment climate, which in the case of this study was set at $0.44^{\circ} \times 3$ over $0.44^{\circ} \times 3$, which is the RCM models' resolution degraded by a factor of 3 . In data available regions, historical RCM based discharges should necessarily be compared to historical observed discharge, which could not be done in the current study.

\subsection{Discharge change}

A mixed annual discharge change signal is projected by the climate models' ensemble for the period of 2021-2050. These trends agree with several studies in the region (Table 7), although all were carried out at the mesoscale and macroscale.

- Negative trend (CCLM-ESM and CCLM-EARTH): a discharge decrease of 30 to $46 \%$ is reported by Ruelland et al. (2012) using MadCM3 and MPI-M in the Bani catchment. A similar trend, resulting from a combination of temperature increase and precipitation decrease, was reached by Mbaye et al. (2015) using the REMO climate model in the Upper Senegal Basin, as did Cornelissen et al. (2013) and Bossa et al. (2014) in the Térou and Ouémé catchments in Benin, respectively.
- Positive trend (CCLM-CNRM, RAMCO-EARTH, and HIRHAM-NorESM): an increase of $38 \%$ in annual discharge in the region is reported by Ardoin-Bardin et al. (2009) for the Sassandra catchment (south of the Dano catchment) using climate projections of HadCM3-A2. This results from a $11 \%$ increase in precipitation not counterbalanced by the $4.5 \%$ increase in potential evapotranspiration.

- Mixed trend (HIRHAM-EARTH and RCM-GCM ensemble): a mixed discharge change signal for the future period is the common signal projected by multi-climate model studies performed in the West African region. In the Niger basin, Aich et al. (2014) simulated change in annual discharge ranging from an increase of up to $50 \%$ to a decrease of up to $50 \%$ using an ensemble of five climate models. Similar signals are reported by Kasei (2009), who applied two climate models (MM5 and REMO) in the Volta basin.

This mixed hydrological change signal is the result of high uncertainties associated with the precipitation change projected by climate models for the catchment (IPCC, 2014). The Wilcoxon rank-sum test further indicated that bias correction did not significantly alter these discharge change signals. Due to the high sensitivity and nonlinear response of the catchment discharge to precipitation, any change in precipitation will have a strong impact on the discharge; the impact will further be pronounced under RCP8.5 compared to RCP4.5. Irrespective of emission scenario, change in potential evapotranspiration alone failed to strongly explain change in annual discharge (Fig. 10a); this is partly explained by the fact that the environmental system of the catchment is water limited and not energy limited.

The water limited environment of the catchment might also explain the performance of the hydrological model for the climate models' ensemble despite the non bias correction of temperature data (up to $4{ }^{\circ} \mathrm{C}$ gaps between observed and simulated temperature were noticed for some months, Sect. 3.1). The annual evaporative demand for the climate models' ensemble, including RACMO-EARTH which underestimated observed temperature for the reference period, exceeds (almost doubles) precipitation (Table 6). In such a system, also characterized by extended periods with little to no precipitation (November-May), actual evapotranspiration is strongly controlled by precipitation (Guswa, 2005; Schenk and Jackson, 2002). Therefore, an increase in $\mathrm{ET}_{\mathrm{p}}$ is not necessarily translated into an increase in $\mathrm{ET}_{\mathrm{a}}$ as limitation in precipitation (soil moisture) dictates water fluxes (Newman et al., 2006) (e.g., CCLM-EARTH and CCLM-ESM in Table 6). 


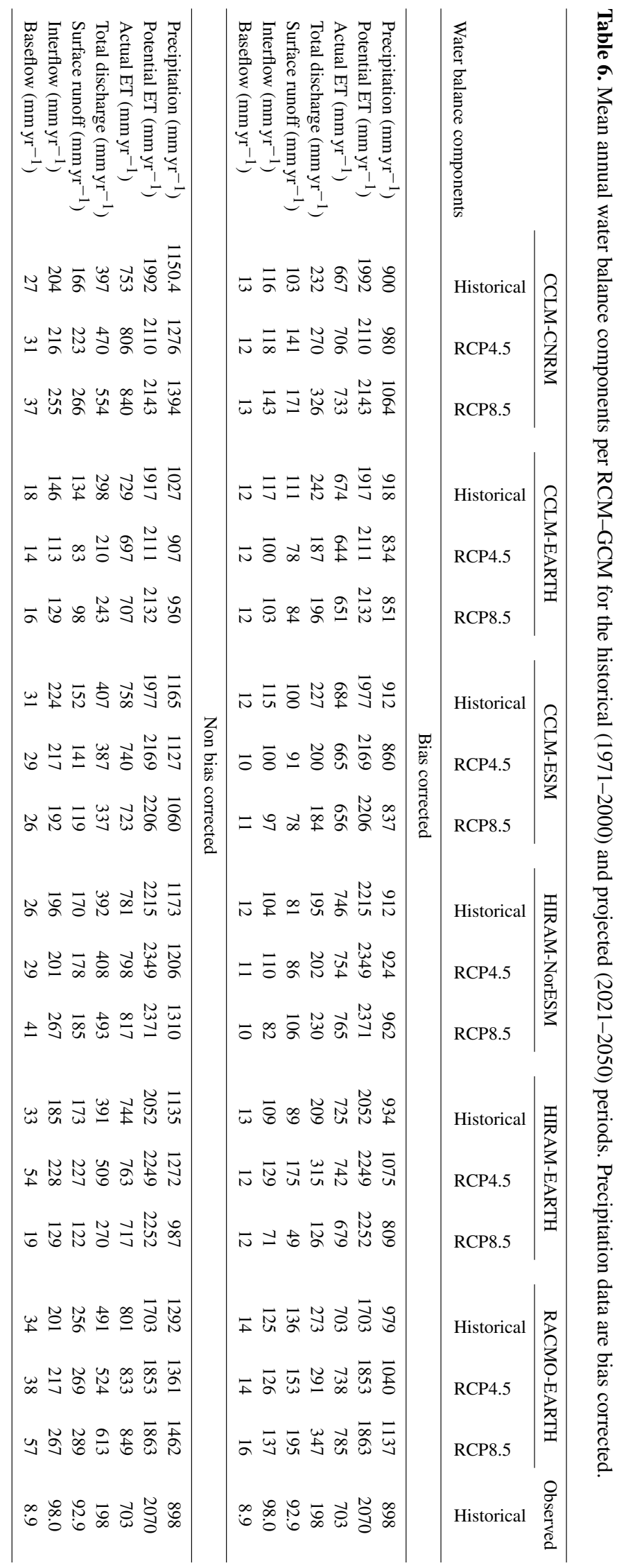


Table 7. Selected studies of climate impact on water resources in the West African region.

\begin{tabular}{|c|c|c|c|c|c|c|c|}
\hline Study & Location/size & $\mathrm{GCM} / \mathrm{RCM}$ & Scenario & $\begin{array}{l}\text { Reference } \\
\text { period }\end{array}$ & $\begin{array}{l}\text { Future } \\
\text { period }\end{array}$ & $\begin{array}{l}\text { Precipitation } \\
\text { change }(\%)\end{array}$ & $\begin{array}{l}\text { Discharge } \\
\text { change }(\%)\end{array}$ \\
\hline $\begin{array}{l}\text { Ruelland et al. } \\
\text { (2012) }\end{array}$ & $\begin{array}{l}\text { Bani catchment, } \\
\text { Mali/100 } 000 \mathrm{~km}^{2}\end{array}$ & MadCM3 and MPI-M & A2 & $1961-1990$ & 2041-2070 & -2 to -10 & -30 to -46 \\
\hline Mbaye et al. (2015) & $\begin{array}{l}\text { Upper Senegal } \\
\text { Basin, Senegal- } \\
\text { Mali-Mauritania/ } \\
21800 \mathrm{~km}^{2}\end{array}$ & $\begin{array}{l}\text { REMO-MPI-ESM- } \\
\text { LR }\end{array}$ & $\begin{array}{l}\text { RCP4.5 } \\
\text { and } \\
\text { RCP8.5 }\end{array}$ & $1971-2000$ & $2071-2100$ & negative trend & up to -80 \\
\hline Aich et al. (2014) & $\begin{array}{l}\text { Niger Basin/ } \\
2156000 \mathrm{~km}^{2}\end{array}$ & $\begin{array}{l}\text { HadGEM2-ES, } \\
\text { IPSL-5 CM5A-LR, } \\
\text { MIROC-ESM-CHEM, } \\
\text { GFDL-ESM2M, } \\
\text { NorESM1-M }\end{array}$ & RCP8.5 & 1970-1999 & 2070-2099 & mixed trend & -50 to +50 \\
\hline $\begin{array}{l}\text { Ardoin-Bardin et al. } \\
\text { (2009) }\end{array}$ & $\begin{array}{l}\text { Sassandra, Ivory } \\
\text { Coast } / 62173 \mathrm{~km}^{2}\end{array}$ & HadCM3-A2 & - & 1971-1995 & $2036-2065$ & 11.4 & 38 \\
\hline Bossa et al. (2014) & $\begin{array}{l}\text { Ouémé catchment, } \\
\text { Benin/49 } 256 \mathrm{~km}^{2}\end{array}$ & $\begin{array}{l}\text { REMO-ECHAM5/ } \\
\text { MPI-OM }\end{array}$ & A1B & 2000-2009 & $2010-2029$ & -10 & -18 \\
\hline $\begin{array}{l}\text { Cornelissen et al. } \\
\text { (2013) }\end{array}$ & $\begin{array}{l}\text { Térou Catchment, } \\
\text { Benin } / 2344 \mathrm{~km}^{2}\end{array}$ & $\begin{array}{l}\text { REMO-ECHAM5/ } \\
\text { MPI-OM }\end{array}$ & B1 & 2001-2010 & 2031-2049 & -11 & -11 \\
\hline Kasei (2009) & $\begin{array}{l}\text { Volta Basin/ } \\
400000 \mathrm{~km}^{2}\end{array}$ & MM5 and REMO & B1 & $\begin{array}{l}1991-2000 \\
\text { and } \\
1961-2000\end{array}$ & $\begin{array}{l}2030-2039 \\
\text { and } \\
2001-2050\end{array}$ & +12 and -6 & +40 and -5 \\
\hline
\end{tabular}

\subsection{Ecohydrologic status}

The $E_{\mathrm{ex}}-P_{\mathrm{ex}}$ plot (Fig. 11) allows accurate displaying of climate change impact on the catchment hydrology, as main water balance components (precipitation, discharge, and evapotranspiration) are presented in an integrated manner. The overall ecohydrologic effect of climate change on the catchment, as shown by the plots, is a trend towards drier environmental conditions due to increased evaporative demand- $E_{\mathrm{ex}}$. This denotes an increase in potential evapotranspiration higher than the increase in actual evapotranspiration. By contrast, change in the proportion of precipitation converted to discharge- $P_{\text {ex }}$ appears specific to each climate model, with a marginal trend towards discharge increase for the models' ensemble under RCP4.5 and discharge decrease under RCP8.5.

All the climate models that project a precipitation increase result in an ETa increase due to the warmer climate. For some of the climate scenarios the projected increase in ETa outperforms the increase in precipitation, resulting in a decrease in river discharge (unused water). This indicates that the catchment ecosystem (defined as the vegetation within the catchment and provided by the land use and land cover map of the catchment) is able to optimize the use of water and energy available in the environment, thus reducing unused water $\left(P_{\mathrm{ex}}\right)$ with temperature increase (Caylor et al., 2009). Such an optimization, although not investigated in this study, may lead plants to change the allocation of fixed carbon to various tissues and organs (Collins and Bras, 2007; Milne et al., 2002). The suitability of the catchment area for the current plant species could also be affected (McClean et al., 2005) by the projected climate change.

In a previous study (Yira et al., 2016), land use in the catchment was found to be characterized by conversion from savannah to cropland, implying the reduction of the vegetation-covered fraction, root depth, leaf area index, etc. Such a land use and land cover change strongly affects the ecohydrologic status of a catchment. Tomer and Schilling (2009) highlighted that removal of perennial vegetation leads to an increase in both Excess Water- $P_{\text {ex }}$ and Excess evaporative demand- $E_{\mathrm{ex}}$. Combining this land use change with climate change impact would therefore on the one hand aggravate water stress for plants in the catchment and on the other hand increase the unused water in the catchment.

\section{Conclusion}

An ensemble of six RCM-GCM data, all produced in the framework of the CORDEX-Africa project, were used as input to a hydrological simulation model to investigate climate change impact on water resources in the Dano catchment by the mid-21st century. The ability of the RCM-GCM ensem- 
ble to simulate historical climate and discharge was evaluated prior to future climate change impact assessment.

The six climate models fairly reproduce the observed temperature. By contrast, bias correction was necessary for all climate models to accurately reproduce observed precipitation and historical discharge. The applied bias correction method further proved not to alter the discharge change signal. However, projected discharge change signals with and without bias corrected data were tested very comparably. This result indicates that (i) it is safe to perform bias correction; (ii) bias correction improves the quality of climate models' outputs; and (iii) it is not necessary to perform bias correction in order to detect a future discharge change signal in the catchment when relative changes in climate variables are used as reported by several authors (e.g., Muerth et al., 2013; Hagemann et al., 2011).

A temperature increase is consistently projected by the models' ensemble. This reinforces the commonly acknowledged warming signal for the region. However, the lack of agreement among models with regard to the projected precipitation change signal creates considerable uncertainty about how the catchment discharge will evolve by 2050. As discharge in the catchment is strongly determined by precipitation, no clear trend in future development of water resources can be concluded due to the high variability of the different climate models and scenarios. Therefore, potential increase and decrease in future discharge have to be considered in climate change adaptation strategies in the region.

The ecohydrological concept as applied in this study proved to fully capture climate change impact on the hydrological conditions within the catchment as both discharge change signal, precipitation, and actual/potential evapotranspiration change signal are consistently displayed by the $E_{\text {ex }}-P_{\text {ex }}$ plot; it further brings insights into the catchment hydro-climatic conditions, which can assist in development of climate change adaptation strategies. The adopted "one node at a time" approach also appears suitable for the assessment of climate change impact on catchment hydrology of small-scale catchments. The approach enables the use of climate model input for catchments which are much smaller than the size of one climate model grid cell and, hence, approximate climate impact analyses for this scale.

The results further underline on the one hand the need for a larger ensemble of projections to properly estimate the impacts of climate change on water resources in the catchment and on the other hand the high uncertainty associated with climate projections for the West African region. Therefore, assessing future climate change impact on water resources for the region needs to be continuously updated with the improvement of climate projections.

Data availability. The CORDEX-Africa data applied in this study are publicly accessible at https://esg-dn1.nsc.liu.se/search/esgf-liu/.

\section{The Supplement related to this article is available online at doi:10.5194/hess-21-2143-2017-supplement.}

Competing interests. The authors declare that they have no conflict of interest.

Acknowledgements. The authors are grateful for the financial support provided by the German Federal Ministry of Education and Research (BMBF) (grant no. 01LG1202E) under the auspices of the West African Science Service Centre for Climate Change and Adapted Land Use (WASCAL) project. They thank J. Schulla for providing support for the application of WaSiM. Thanks go to the CORDEX project and partner institutions for making climate data available and to D. Wisser for providing a R-code for bias correction. T. Jütten and F. Op de Hipt are acknowledged for their comments on the manuscript. We thank the editor and the anonymous HESS reviewers for their constructive comments.

Edited by: E. Zehe

Reviewed by: two anonymous referees

\section{References}

Ahmed, K. F., Wang, G., Silander, J., Wilson, A. M., Allen, J. M., Horton, R., and Anyah, R.: Statistical downscaling and bias correction of climate model outputs for climate change impact assessment in the U.S. northeast, Global Planet. Change, 100, 320 332, doi:10.1016/j.gloplacha.2012.11.003, 2013.

Aich, V., Liersch, S., Vetter, T., Huang, S., Tecklenburg, J., Hoffmann, P., Koch, H., Fournet, S., Krysanova, V., Müller, E. N., and Hattermann, F. F.: Comparing impacts of climate change on streamflow in four large African river basins, Hydrol. Earth Syst. Sci., 18, 1305-1321, doi:10.5194/hess-18-1305-2014, 2014.

Aich, V., Liersch, S., Vetter, T., Fournet, S., Andersson, J. C. M., Calmanti, S., van Weert, F. H. A., Hattermann, F. F., and Paton, E. N.: Flood projections within the Niger River Basin under future land use and climate change, Sci. Total Environ., 562, 666-677, doi:10.1016/j.scitotenv.2016.04.021, 2016.

Ardoin-Bardin, S., Dezetter, A., Servat, E., Paturel, J. E., Mahé, G., Niel, H., and Dieulin, C.: Using general circulation model outputs to assess impacts of climate change on runoff for large hydrological catchments in West Africa, Hydrolog. Sci. J. 54, 7789, doi:10.1623/hysj.54.1.77, 2009.

Bossa, A. Y., Diekkrüger, B., Giertz, S., Steup, G., Sintondji, L. O., Agbossou, E. K., and Hiepe, C.: Modeling the effects of crop patterns and management scenarios on $\mathrm{N}$ and $\mathrm{P}$ loads to surface water and groundwater in a semi-humid catchment (West Africa), Agr. Water Manage., 115, 20-37, doi:10.1016/j.agwat.2012.08.011, 2012.

Bossa, A. Y., Diekkrüger, B., and Agbossou, E. K.: Scenario-Based Impacts of Land Use and Climate Change on Land and Water Degradation from the Meso to Regional Scale, Water, 6, 31523181, doi:10.3390/w6103152, 2014.

Buontempo, C., Mathison, C., Jones, R., Williams, K., Wang, C., and McSweeney, C.: An ensemble climate projection for Africa, Clim. Dynam., 44, 2097-2118, doi:10.1007/s00382-014-2286-2, 2014. 
Caylor, K. K., Scanlon, T. M., and Rodriguez-Iturbe, I.: Ecohydrological optimization of pattern and processes in water-limited ecosystems: A trade-off-based hypothesis, Water Resour. Res., 45, W08407, doi:10.1029/2008WR007230, 2009.

Chen, J., Brissette, F. P., Chaumont, D., and Braun, M.: Performance and uncertainty evaluation of empirical downscaling methods in quantifying the climate change impacts on hydrology over two North American river basins, J. Hydrol., 479, 200-214, doi:10.1016/j.jhydrol.2012.11.062, 2013.

Collins, D. B. G. and Bras, R. L.: Plant rooting strategies in water-limited ecosystems, Water Resour. Res., 43, W06407, doi:10.1029/2006WR005541, 2007.

Cook, K. H.: Climate science: The mysteries of Sahel droughts, Nat. Geosci., 1, 647-648, doi:10.1038/ngeo320, 2008.

Cook, K. H. and Vizy, E. K.: Coupled Model Simulations of the West African Monsoon System: Twentieth- and Twenty-First-Century Simulations, J. Climate, 19, 3681-3703, doi:10.1175/JCLI3814.1, 2006.

Cornelissen, T., Diekkrüger, B., and Giertz, S.: A comparison of hydrological models for assessing the impact of land use and climate change on discharge in a tropical catchment, J. Hydrol., 498, 221-236, doi:10.1016/j.jhydrol.2013.06.016, 2013.

Dosio, A., Panitz, H.-J., Schubert-Frisius, M., and Lüthi, D.: Dynamical downscaling of CMIP5 global circulation models over CORDEX-Africa with COSMO-CLM: evaluation over the present climate and analysis of the added value, Clim. Dynam., 44, 2637-2661, doi:10.1007/s00382-014-2262-x, 2015.

Druyan, L. M., Feng, J., Cook, K. H., Xue, Y., Fulakeza, M., Hagos, S. M., Konaré, A., Moufouma-Okia, W., Rowell, D. P., Vizy, E. K., and Ibrah, S. S.: The WAMME regional model intercomparison study, Clim. Dynam., 35, 175-192, doi:10.1007/s00382009-0676-7, 2009.

Ehret, U., Zehe, E., Wulfmeyer, V., Warrach-Sagi, K., and Liebert, J.: HESS Opinions "Should we apply bias correction to global and regional climate model data?", Hydrol. Earth Syst. Sci., 16, 3391-3404, doi:10.5194/hess-16-3391-2012, 2012.

Feddes, R. A., Kowalik, P. J., and Zaradny, H.: Simulation of field water use and crop yield, Centre for Agricultural Publishing and Documentation, Wageningen, the Netherlands, 1978.

Federer, C. A. and Lash, D.: BROOK - a hydrologic simulation model for eastern forests, Resources Research Center, University of New Hampshire, New Hampshire, 1983.

Foley, A. M.: Uncertainty in regional climate modelling: A review, Prog. Phys. Geogr., 34, 647-670, doi:10.1177/0309133310375654, 2010.

Gbobaniyi, E., Sarr, A., Sylla, M. B., Diallo, I., Lennard, C., Dosio, A., Dhiédiou, A., Kamga, A., Klutse, N. A. B., Hewitson, B., Nikulin, G., and Lamptey, B.: Climatology, annual cycle and interannual variability of precipitation and temperature in CORDEX simulations over West Africa, Int. J. Climatol., 34, 2241-2257, doi:10.1002/joc.3834, 2014.

Gudmundsson, L., Bremnes, J. B., Haugen, J. E., and EngenSkaugen, T.: Technical Note: Downscaling RCM precipitation to the station scale using statistical transformations - a comparison of methods, Hydrol. Earth Syst. Sci., 16, 3383-3390, doi:10.5194/hess-16-3383-2012, 2012.

Gupta, H. V., Kling, H., Yilmaz, K. K., and Martinez, G. F.: Decomposition of the mean squared error and NSE performance criteria:
Implications for improving hydrological modelling, J. Hydrol., 377, 80-91, doi:10.1016/j.jhydrol.2009.08.003, 2009.

Guswa, A. J.: Soil-moisture limits on plant uptake: An upscaled relationship for water-limited ecosystems, Adv. Water Resour., 28, 543-552, doi:10.1016/j.advwatres.2004.08.016, 2005.

Hagemann, S., Chen, C., Haerter, J. O., Heinke, J., Gerten, D., and Piani, C.: Impact of a Statistical Bias Correction on the Projected Hydrological Changes Obtained from Three GCMs and Two Hydrology Models, J. Hydrometeorol., 12, 556-578, doi:10.1175/2011JHM1336.1, 2011.

IPCC: Climate change 2014: impacts, adaptation, and vulnerability, in: Part B: regional aspects. Contribution of Working Group II to the Fifth Assessment Report of the Intergovernmental Panel on Climate Change, edited by: Barros, V. R., Field, C. B., Dokken, D. J., Mastrandrea, M. D., Mach, K. J., Bilir, T. E., Chatterjee, M., Ebi, K. L., Estrada, Y. O., Genova, R. C., Girma, B., Kissel, E. S., Levy, A. N., MacCracken, S., Mastrandrea, P. R., and White, L. L., Cambridge University Press, Cambridge, UKand New York, NY, USA, 1133-1820, 2014.

Johnson, F. and Sharma, A.: What are the impacts of bias correction on future drought projections?, J. Hydrol., 525, 472-485, doi:10.1016/j.jhydrol.2015.04.002, 2015.

Karambiri, H., García Galiano, S. G., Giraldo, J. D., Yacouba, H., Ibrahim, B., Barbier, B., and Polcher, J.: Assessing the impact of climate variability and climate change on runoff in West Africa: the case of Senegal and Nakambe River basins, Atmos. Sci. Lett., 12, 109-115, doi:10.1002/asl.317, 2011.

Kasei, R. A.: Modelling impacts of climate change on water resources in the Volta Basin, West Africa, PhD Thesis, University of Bonn, Bonn, Germany, http://hss.ulb.uni-bonn.de/2010/1977/ 1977.pdf (last access: 23 April 2015), 2009.

Kasei, R. A., Diekkrüger, B., and Leemhuis, C.: Drought frequency in the Volta Basin of West Africa, Sustain. Sci., 5, 89-97, doi:10.1007/s11625-009-0101-5, 2009.

Klein, C., Heinzeller, D., Bliefernicht, J., and Kunstmann, H.: Variability of West African monsoon patterns generated by a WRF multi-physics ensemble, Clim. Dynam., 45, 2733-2755, doi:10.1007/s00382-015-2505-5, 2015.

Kling, H., Fuchs, M., and Paulin, M.: Runoff conditions in the upper Danube basin under an ensemble of climate change scenarios, J. Hydrol., 424-425, 264-277, doi:10.1016/j.jhydrol.2012.01.011, 2012.

Kunstmann, H., Jung, G., Wagner, S., and Clottey, H.: Integration of atmospheric sciences and hydrology for the development of decision support systems in sustainable water management, Phys. Chem. Earth Pts. ABC, 33, 165-174, doi:10.1016/j.pce.2007.04.010, 2008.

Lafon, T., Dadson, S., Buys, G., and Prudhomme, C.: Bias correction of daily precipitation simulated by a regional climate model: a comparison of methods, Int. J. Climatol., 33, 13671381, doi:10.1002/joc.3518, 2013.

Mbaye, M. L., Hagemann, S., Haensler, A., Stacke, T., Gaye, A. T., and Afouda, A.: Assessment of Climate Change Impact on Water Resources in the Upper Senegal Basin (West Africa), Am. J. Clim. Change, 4, 77-93, doi:10.4236/ajcc.2015.41008, 2015.

McClean, C. J., Lovett, J. C., Küper, W., Hannah, L., Sommer, J. H., Barthlott, W., Termansen, M., Smith, G. F., Tokumine, S., and Taplin, J. R. D.: African Plant Diversity and Climate Change, Ann. Mo. Bot. Gard., 92, 139-152, 2005. 
Milne, B. T., Gupta, V. K., and Restrepo, C.: A scale invariant coupling of plants, water, energy, and terrain, Écoscience, 9, 191199, 2002.

Moss, R. H., Edmonds, J. A., Hibbard, K. A., Manning, M. R., Rose, S. K., van Vuuren, D. P., Carter, T. R., Emori, S., Kainuma, M., Kram, T., Meehl, G. A., Mitchell, J. F. B., Nakicenovic, N., Riahi, K., Smith, S. J., Stouffer, R. J., Thomson, A. M., Weyant, J. P., and Wilbanks, T. J.: The next generation of scenarios for climate change research and assessment, Nature, 463, 747-756, doi:10.1038/nature08823, 2010.

Muerth, M. J., Gauvin St-Denis, B., Ricard, S., Velázquez, J. A., Schmid, J., Minville, M., Caya, D., Chaumont, D., Ludwig, R., and Turcotte, R.: On the need for bias correction in regional climate scenarios to assess climate change impacts on river runoff, Hydrol. Earth Syst. Sci., 17, 1189-1204, doi:10.5194/hess-171189-2013, 2013.

Murphy, A. H.: What Is a Good Forecast? An Essay on the Nature of Goodness in Weather Forecasting, Weather Forecast., 8, 281-293, doi:10.1175/15200434(1993)008<0281:WIAGFA>2.0.CO;2, 1993.

Nash, J. E. and Sutcliffe, J. V.: River flow forecasting through conceptual models part I - A discussion of principles, J. Hydrol., 10, 282-290, doi:10.1016/0022-1694(70)90255-6, 1970.

Newman, B. D., Wilcox, B. P., Archer, S. R., Breshears, D. D., Dahm, C. N., Duffy, C. J., McDowell, N. G., Phillips, F. M., Scanlon, B. R., and Vivoni, E. R.: Ecohydrology of waterlimited environments: A scientific vision, Water Resour. Res., 42, W06302, doi:10.1029/2005WR004141, 2006.

Nikulin, G., Jones, C., Giorgi, F., Asrar, G., Büchner, M., CerezoMota, R., Christensen, O. B., Déqué, M., Fernandez, J., Hänsler, A., van Meijgaard, E., Samuelsson, P., Sylla, M. B., and Sushama, L.: Precipitation Climatology in an Ensemble of CORDEX-Africa Regional Climate Simulations, J. Climate, 25, 6057-6078, doi:10.1175/JCLI-D-11-00375.1, 2012.

Oguntunde, P. G. and Abiodun, B. J.: The impact of climate change on the Niger River Basin hydroclimatology, West Africa, Clim. Dynam., 40, 81-94, doi:10.1007/s00382-012-1498-6, 2012.

Oyerinde, G. T., Hountondji, F. C. C., Wisser, D., Diekkrüger, B., Lawin, A. E., Odofin, A. J., and Afouda, A.: Hydro-climatic changes in the Niger basin and consistency of local perceptions, Reg. Environ. Change, 15, 1627-1637, doi:10.1007/s10113-0140716-7, 2014.

Paeth, H., Hall, N. M. J., Gaertner, M. A., Alonso, M. D., Moumouni, S., Polcher, J., Ruti, P. M., Fink, A. H., Gosset, M., Lebel, T., Gaye, A. T., Rowell, D. P., Moufouma-Okia, W., Jacob, D., Rockel, B., Giorgi, F., and Rummukainen, M.: Progress in regional downscaling of west African precipitation, Atmos. Sci. Lett., 12, 75-82, doi:10.1002/asl.306, 2011.

Patricola, C. M. and Cook, K. H.: Northern African climate at the end of the twenty-first century: an integrated application of regional and global climate models, Clim. Dynam., 35, 193-212, doi:10.1007/s00382-009-0623-7, 2009.

Piani, C., Weedon, G. P., Best, M., Gomes, S. M., Viterbo, P., Hagemann, S., and Haerter, J. O.: Statistical bias correction of global simulated daily precipitation and temperature for the application of hydrological models, J. Hydrol., 395, 199-215, doi:10.1016/j.jhydrol.2010.10.024, 2010.
Roudier, P., Ducharne, A., and Feyen, L.: Climate change impacts on runoff in West Africa: a review, Hydrol. Earth Syst. Sci., 18, 2789-2801, doi:10.5194/hess-18-2789-2014, 2014.

Ruelland, D., Ardoin-Bardin, S., Collet, L., and Roucou, P.: Simulating future trends in hydrological regime of a large SudanoSahelian catchment under climate change, J. Hydrol., 424-425, 207-216, doi:10.1016/j.jhydrol.2012.01.002, 2012.

Ruti, P. M., Williams, J. E., Hourdin, F., Guichard, F., Boone, A., Van Velthoven, P., Favot, F., Musat, I., Rummukainen, M., Domínguez, M., Gaertner, M. Á., Lafore, J. P., Losada, T., Rodriguez de Fonseca, M. B., Polcher, J., Giorgi, F., Xue, Y., Bouarar, I., Law, K., Josse, B., Barret, B., Yang, X., Mari, C., and Traore, A. K.: The West African climate system: a review of the AMMA model inter-comparison initiatives, Atmos. Sci. Lett., 12, 116-122, doi:10.1002/asl.305, 2011.

Salack, S., Sarr, B., Sangare, S. K., Ly, M., Sanda, I. S., and Kunstmann, H.: Crop-climate ensemble scenarios to improve risk assessment and resilience in the semi-arid regions of West Africa, Clim. Res., 65, 107-121, doi:10.3354/cr01282, 2015.

Schenk, H. J. and Jackson, R. B.: Rooting depths, lateral root spreads and below-ground/above-ground allometries of plants in water-limited ecosystems, J. Ecol., 90, 480-494, doi:10.1046/j.1365-2745.2002.00682.x, 2002.

Schmengler, A. C.: Modeling Soil Erosion and Reservoir Sedimentation at Hillslope and Catchment Scale in Semi-Arid Burkina Faso, PhD Thesis, University of Bonn, Bonn, Germany, 2011.

Schulla, J.: Model Description WaSiM, http://wasim.ch/downloads/ doku/wasim/wasim_2015_en.pdf (last access: 17 June 2016), 2015.

Sylla, M. B., Elguindi, N., Giorgi, F., and Wisser, D.: Projected robust shift of climate zones over West Africa in response to anthropogenic climate change for the late 21st century, Climatic Change, 134, 241-253, doi:10.1007/s10584-015-1522-z, 2015.

Teutschbein, C. and Seibert, J.: Bias correction of regional climate model simulations for hydrological climate-change impact studies: Review and evaluation of different methods, J. Hydrol., 456457, 12-29, doi:10.1016/j.jhydrol.2012.05.052, 2012.

Teutschbein, C. and Seibert, J.: Is bias correction of regional climate model (RCM) simulations possible for nonstationary conditions?, Hydrol. Earth Syst. Sci., 17, 5061-5077, doi:10.5194/hess-17-5061-2013, 2013.

Tomer, M. D. and Schilling, K. E.: A simple approach to distinguish land-use and climate-change effects on watershed hydrology, J. Hydrol., 376, 24-33, doi:10.1016/j.jhydrol.2009.07.029, 2009.

van Genuchten, M. T.: A Closed-form Equation for Predicting the Hydraulic Conductivity of Unsaturated Soils, Soil Sci. Soc. Am. J., 44, 892-898, doi:10.2136/sssaj1980.03615995004400050002x, 1980.

Waongo, M.: Optimizing Planting Dates for Agricultural DecisionMaking under Climate Change over Burkina Faso/West Africa, $\mathrm{PhD}$ Thesis, Augsburg, Germany, https://opus.bibliothek. uni-augsburg.de/opus4/frontdoor/index/index/docId/3280, last access: 29 October 2015.

Waongo, M., Laux, P., and Kunstmann, H.: Adaptation to climate change: The impacts of optimized planting dates on attainable maize yields under rainfed conditions in Burkina Faso, Agr. Forest Meteorol., 205, 23-39, doi:10.1016/j.agrformet.2015.02.006, 2015 . 
Wilcoxon, F.: Individual Comparisons by Ranking Methods, Biom. Bull., 1, 80-83, doi:10.2307/3001968, 1945

WRB, I.U.S.S.W.G.: World reference base for soil resources, World Soil Resources Reports No. 103, Food \& Agriculture Org., Rome, 2006.

Yira, Y., Diekkrüger, B., Steup, G., and Bossa, A. Y.: Modeling land use change impacts on water resources in a tropical West African catchment (Dano, Burkina Faso), J. Hydrol., 537, 187199, doi:10.1016/j.jhydrol.2016.03.052, 2016.
Zhang, H., Huang, G. H., Wang, D., and Zhang, X.: Uncertainty assessment of climate change impacts on the hydrology of small prairie wetlands, J. Hydrol., 396, 94-103, doi:10.1016/j.jhydrol.2010.10.037, 2011. 